Notre Dame Law School

NDLScholarship

Journal Articles

Publications

1992

\title{
Doctrinal Synergies and Liberal Dilemmas: The Case of the Yellow-Dog Contract
}

Barry Cushman

Notre Dame Law School, bcushman@nd.edu

Follow this and additional works at: https://scholarship.law.nd.edu/law_faculty_scholarship

Part of the Contracts Commons, and the Labor and Employment Law Commons

\section{Recommended Citation}

Barry Cushman, Doctrinal Synergies and Liberal Dilemmas: The Case of the Yellow-Dog Contract, 1992 Sup. Ct. Rev. 235 (1993).

Available at: https://scholarship.law.nd.edu/law_faculty_scholarship/1247

This Article is brought to you for free and open access by the Publications at NDLScholarship. It has been accepted for inclusion in Journal Articles by an authorized administrator of NDLScholarship. For more information, please contact lawdr@nd.edu. 
The three decades spanning the years 1908 to 1937 saw a remarkable transformation of the Supreme Court's jurisprudence concerning the rights of workers to organize. In 1908, the court held that a federal law prohibiting employers from discharging an employee because of his membership in a labor union violated the liberty of contract secured to the employer by the Fifth Amendment. ${ }^{1}$ In 1915 , the Court similarly declared a state statute prohibiting the use of "yellow-dog" contracts unconstitutional. ${ }^{2}$ In 1937, by contrast, the Court upheld provisions of the Wagner Act prohibiting both discharges for union membership and the use of yellow-dog contracts. ${ }^{3}$ Thus, the doctrine of "liberty of contract" no longer operated as a bar to legislation protecting the rights of workers to organize for purposes of collective bargaining.

Barry Cushman is Assistant Professor of Law, St. Louis University School of Law.

AurHoR's Note: The author gratefully acknowledges the valuable criticisms of Patrice Cushman, Chris Eisgruber, Daniel Ernst, Roger Goldman, John Griesbach, Michael Klarman, Charles McCurdy, William Nelson, John Phillip Reid, Reuel Schiller, Doug Williams, and the members of the Legal History Colloquium at the New York University School of Law.

${ }^{1}$ Adair v United States, 208 US 161 (1908).

${ }^{2}$ Coppage v Kansas, 236 US 1 (1915). A "yellow-dog" contract was a contract of employment in which the employee would agree, as a condition of his employment, not to join a labor union.

${ }^{3}$ NLRB v Jones \& Laugblin Steel Corp., 301 US 1 (1937); NLRB v Fruebauf Trailer Co., 301 US 49 (1937); NLRB v Friedman-Harry Marks Clotbing Co., 301 US 58 (1937); Associated Press Co. $v$ NLRB, 301 US 103 (1937); Wasbington, Virginia \& Maryland Coacb Co. v NLRB, 301 US 142 (1937).

(C) 1993 by The University of Chicago. All rights reserved.

$0-226-36247-7 / 93 / 1992-0007 \$ 02.00$ 
Remarkably, the intellectual history of this transformation has not been written. Historians writing about the Wagner Act cases, preoccupied by the more dramatic commerce clause issues, have tended to give only cursory treatment to the due process dimensions of the decisions. ${ }^{4}$ The outcome of the cases has been seen as an essentially political response to the external political pressure brought to bear by the Court-packing plan and the 1936 election. $^{5}$ This explanation has apparently been seen as obviating any sustained conceptual or doctrinal analysis. ${ }^{6}$

The tale of the yellow-dog contract is naturally of interest because of its centrality to the development of American labor law and the decline of substantive due process. Beyond this, however, the story can be seen as a critical chapter in the development of American liberal legalism. The yellow-dog contract provoked something of a crisis in liberal discourse, because it brought into conflict two time-honored liberal values: liberty of contract and freedom of association. Recent scholarship has shown how "liberty of contract" was forged from such diverse liberal resources as Adam Smith's liberal political economy, Jacksonian liberalism, and the Northern "free labor" ideology that animated the abolitionist movement. ${ }^{7}$ Freedom of association enjoyed no less venerable liberal

\footnotetext{
${ }^{4}$ See, e.g., Peter Irons, The New Deal Lawyers 287-88 (Princeton Univ, 1982); Kelly \& Harbison, The American Constitution: Its Origins and Development 766-77 (Norton, 4th ed 1970); Mason \& Beaney, The Supreme Court in a Free Society 182-84 (Norton, 1968); Robert McCloskey, The American Supreme Court 176 (Univ of Chicago, 1960); Paul Murphy, Tbe Constitution in Crisis Times, 1918-1969, 157-58 (Harper \& Row, 1972); Fred Rodell, Nine Men 249-250 (Vintage, 1955); Bernard Schwartz, Tbe Supreme Court: Constitutional Revolution in Retrospect 21-22, 34-36 (Ronald Press, 1957); William Swindler, 2 Court and Constitution in the Twentietb Century: Tbe New Legality, 1932-1968, 99-100 (Bobbs-Merrill, 1968); Benjamin Wright, Tbe Growtb of American Constitutional Law 204-5 (H Holt, 1942).

${ }^{5}$ See, e.g., Edward Corwin, Court Over Constitution 127 (Princeton Univ, 1938); Robert McCloskey, supra at 224; Paul Murphy, supra at 115; Walter Murphy, Congress and the Court: A Case Study in the American Political Process 65 (Univ of Chicago, 1962); William Swindler, supra at 81; Benjamin F. Wright, Tbe Growtb of American Constitutional Law 205, 222 (Univ of Chicago, 1967).

"For a critique of the political response theory, see Cushman, "Retbinking tbe New Deal Court: The "Switcb-in-Time" Reconsidered (forthcoming); Michael J. Klarman, Constitutional Fact/Constitutional Fiction, 44 Stan L Rev 759, 771 n 76, 774-75 n .98 (1992).

${ }^{7}$ See Eric Foner, Free Soil, Free Labor, Free Men: Tbe Idealogy of the Republican Party Bcfore the Civil War (Oxford Univ, 1970); William Forbath, The Ambiguities of Free Labor: Labor and the Law in the Gilded Age, 1985 Wis L Rev 767, 772-800 (1985); Charles McCurdy, Tbe Roots of "Liberty of Contract" Reconsidered: Major Premises in the Law of Employment, 1867-1937, in 1984 Yearbook of tbe Supreme Court Historical Society 20 (1984); William Nelson, Tbe Impact of tbe Antislavery Movement upon Styles of Judicial Reasoning in Nineteenth Century America, $87 \mathrm{Harv}$ L Rev 513 (1974).
} 
pedigree. Its protection against government infringement enshrined in the First Amendment, ${ }^{8}$ the freedom to affiliate with the lawful organizations of one's choice, had been a widely embraced feature of American culture since well before the Civil War. ${ }^{9}$ Indeed, the passion of the American people for voluntary associations had attracted the fascination of Alexis de Tocqueville during his journey to the United States in the 1830s. ${ }^{10}$

The yellow-dog contract exposed a tension between these two values of American liberalism. Opponents of the yellow-dog contract contended that the employer was using his constitutionally protected liberty of contract as a means to inhibit his employee's freedom to associate with his fellow workingmen. In characteristically liberal terms, the answer to this charge would turn on whether the employee was seen as having surrendered his freedom of association voluntarily, or as a product of coercion. The answer to this question would in turn depend upon assumptions about the structure of the labor market-assumptions that would change over tine. Beneath this discourse, I believe, lay concerns about whether labor unions were properly analogized to the other sorts of voluntary associations celebrated by American liberalism. As those concerns became increasingly allayed over time, labor's advocates could more successfully appropriate the liberal rhetoric of.associational freedom.

Yet the story of the yellow dog's demise cannot be adequately understood by looking at cultural context alone. In order to understand the voting patterns of the various Justices and the views they expressed in their opinions, one must pay close attention to the development of doctrine. A study of the doctrine pertaining to the yellow-dog contract reveals to us the poverty of the notion that substantive due process and dual federalism were merely convenient weapons in the arsenal of a reactionary Court devoted to the maintenance of financial and industrial elites. ${ }^{11}$ Instead, we may see the weblike, interconnected structure of laissez-faire constitu-

\footnotetext{
${ }^{8}$ See Nowak, Rotunda \& Young, Constitutional Law § XII, at 958-59 (West, 2d ed 1983).

${ }^{9}$ See Gross, The Minutemen and Their World 173-75 (Hill \& Wang, 1976); Ryan, Cradle of the Middle Clas, ch 3 (Cambridge Univ, 1981); Walters, American Reformers, 1815-1860 29-35 (Hill \& Wang, 1978).

${ }^{10}$ See Alexis de Tocqueville, 2 Democracy in America 128-33, 138-44 (New York, 1972).

"See, e.g., Corwin, Twiligbt of tbe Supreme Court (Yale Univ, 1934).
} 
tionalism. ${ }^{12}$ The doctrinal manifestations of commerce clause and due process jurisprudence were not simply free-floating rules that could be changed or abandoned without consequences extending beyond the particular doctrine involved. These areas of doctrine were developmentally intra- and interdependent. Modifications of one substantive due process doctrine entailed changes in another; developments in due process and commerce clause doctrine produced mutual, synergistic ramifications. In short, doctrinal commitments made by Justices in one area of doctrine entailed corresponding commitments in another area. In order to follow the trail of the yellow dog, we must trace these ripple effects across structurally related areas of doctrine.

\section{Origins: The Erdman Act, Adair v United States, and Coppage v Kansas}

The idea of "liberty of contract" is generally thought to have first appeared in a Supreme Court decision in Allgeyer $v$ Louisiana ${ }^{13}$ decided in 1897; to have entered American constitutional jurisprudence in 1886 with Godcharles $v$ Wigeman $;{ }^{14}$ and to have emerged in American social thought well before the Civil War. ${ }^{15}$ It is curious, then, to note that when Congress enacted the Erdman Act in 1898, no one in either House suggested that its Section 10 was unconstitutional. ${ }^{16}$ That section prohibited interstate carriers from, inter alia, (1) requiring "any employee, or any person seeking employment, as a condition of such employment, to enter" into a so-called "yellow-dog" contract ("an agreement, either written or verbal, not to become or remain a member of any labor corporation, association, or organization"), and (2) "threaten[ing] any employee with

${ }^{12}$ See Cushman, A Stream of Legal Consciousness: The Current of Commerce Doctrine from Swift to Jones \& Laughlin, 61 Fordham L Rev 105 (1992); McCurdy, Justice Field and tbe Jurisprudencc of Government-Business Relations: Some Parameters of Laisez Faire Constitutionalism, 18631897, $61 \mathrm{~J}$ Am Hist 970 (1975).

${ }^{13} 165$ US 578 (1897).

${ }^{14} 133 \mathrm{~Pa} 431$ (1886).

${ }^{15}$ Eric Foner, note 7; William Forbath, Tbe Ambiguities of Free Labor (cited in note 7); Charles McCurdy, note 7; William Nelson, note 7.

${ }^{16}$ See legislative histories of HR 4372, S 3653, and S 3662, 31 Cong Rec 74-5566 (55-2); S Rep 591 (55-2); HR Rep 454 (55-2). For background on the enactment of the Erdman Act, see Gerald Eggert, Railroad Labor Disputes (Univ Michigan, 1967). 
loss of employment" or "unjustly discriminat[ing] against any employee" because of his union membership. ${ }^{17}$ Why, in an era in which constitutional debate on the floor of both Houses of Congress flourished, ${ }^{18}$ did these legislators believe that such abrogations of an employer's common law contractual prerogatives were constitutional?

The opinion of the district court in United States $v$ Adair ${ }^{19}$ suggests the unarticulated rationale on which many in Congress may have relied. The indictment charged that William Adair, master mechanic of the Louisville \& Nashville Railroad Company, had discharged locomotive fireman O. B. Coppage because of the latter's membership in the Order of Locomotive Firemen. Adair's demurrer contended, inter alia, that Section 10 of the Erdman Act violated the liberty of contract secured to him under the Fifth Amendment.

District Judge Andrew M. Cochran conceded that the Fifth Amendment constituted an independent limitation on the federal power to regulate interstate commerce. ${ }^{20}$ The liberty of contract secured to a lawful private business, however, was greater than that secured to a common carrier engaged in interstate commerce. ${ }^{21}$ Because the latter "exercises a public function,"22 held the Court, "[ $t]$ he only possible ground for holding that [Section 10] is in violation of the fifth amendment is that it has no real and substantial relation to the free course of interstate commerce. ${ }^{23}$ Because Section 10's "tendency" was "to prevent an interruption to interstate commerce by reason of strikes, lockouts and boycotts," ${ }^{24}$ it constituted a legitimate regulation of the contractual relations of a business affected with a public interest. In other words, the common carrier's status as a business affected with a public interest rendered it subject to regulations to which a purely private business could

\footnotetext{
1730 Stat 424,428 , ch 370 (55-2).

${ }^{18}$ See Donald G. Morgan, Congress and tbe Constitution: A Study of Responsibility, ch 7 (Belknap, 1966).

${ }^{19} 152 \mathrm{~F} 737$ (ED Ky 1907).

${ }^{20}$ Id at 754-55.

${ }^{21}$ Id at $755-56$.

22 Id at 756.

${ }^{23}$ Id at 759.

${ }^{24}$ Id at 752 .
} 
not constitutionally be subjected; and the relationship between the company's contractual relations with its employees and the free flow of interstate commerce provided the rationale supporting the instant regulation.

A majority of the justices of the United States Supreme Court disagreed with Judge Cochran. The majority opinion, written by Justice John Marshall Harlan, took no notice of the fact that the company was a business traditionally regarded as affected with a public interest, and stated the parties' contractual rights in absolutist terms. ${ }^{25}$

While, as already suggested, the rights of liberty and property guaranteed by the Constitution against deprivation without due process of law, is [sic] subject to such reasonable restraints as the common good or general welfare may require, it is not within the functions of government - at least in the absence of contract between the parties-to compel any person in the course of his business and against his will to accept or retain the personal services of another, or to compel any person, against his will, to perform personal services for another.

The common law prerogative of the employer to discharge his employee at will for any or no reason, Justice Harlan appeared to be saying, was insulated from government regulation by the Due Process Clause of the Fifth Amendment.

Yet despite having held that the statute violated the Fifth Amendment, Harlan went on to entertain at length the suggestion that, the Fifth Amendment notwithstanding, Section 10 might be a legitimate exercise of the federal power to regulate commerce among the states.

At first blush, this seems a curious mode of analysis. The commerce power, after all, was conferred in Article I, Section 8 of the original Constitution of 1787. The Fifth Amendment is an amendment to that document, and accordingly trumps the commerce clause to the extent the two are in conflict. If the Fifth Amendment rendered Section 10 of the Erdman Act unconstitutional, one is led to inquire, how could the statute have been independently sustained under the commerce power? It would seem that Harlan's Fifth Amendment analysis should have ended the inquiry into the statute's constitutionality.

\footnotetext{
${ }^{25}$ Adair v United States, 208 US 161, 174 (1908).
} 
The solution to this puzzle lies in recognizing that Harlan and his colleagues were, like Judge Cochran, reasoning by analogy to Fourteenth Amendment due process cases. The Court had recognized in Holden $v$ Hardy ${ }^{26}$ and Locbner $v$ New York ${ }^{27}$ that the Fourteenth Amendment's Due Process Clause did not prohibit the state from regulating the labor contract if such regnlation was reasonably related to the protection of public health, safety, or morals. Conventionally termed "police powers," these powers to protect public health, safety, and morals were held to be inherent in the sovereignty of the several States; and with these residuary police powers, the Court had held, "the Fourteenth Amendment was not designed to interfere." 28

The federal government, as a government of enumerated powers, did not have residuary police powers. However, Congress did possess a power analogous to the police powers of the state legislatures. Just as the states were empowered to legislate to protect public health, safety, and morals, the federal government was empowered to legislate to protect the free flow of interstate commerce. ${ }^{29}$ Harlan's mode of analysis thus suggests that a majority of the Court believed that the impact of employer-employee relations on interstate commerce might have provided a "commercial police power" rationale for the regulation of rights otherwise secured by the Fifth Amendment.

Yet unlike Judge Cochran, the majority could find no "real and substantial relation" between interstate commerce and the acts proscribed by Section 10. "[W] hat possible legal or logical connection is there between an employee's membership in a labor organization and the carrying on of interstate commerce?" queried Justice Harlan. "Such relation to a labor organization cannot have, in itself and in the eye of the law, any bearing upon the commerce with which the employee is connected by his labor and services." 30

One who engages in the service of an interstate carrier will, it must be assumed, faithfully perform his duty, whether he be a member or not a member of a labor organization. His fitness

\footnotetext{
${ }^{26} 169$ US 366 (1898).

${ }^{27} 198$ US 45 (1905).

${ }^{28}$ Id at 53.

${ }^{29}$ See, e.g., Swift \& Co. v United States, 196 US 375 (1905).

${ }^{30}$ Adair v United States, 208 US 161, 178 (1908) (emphasis in original).
} 
for the position in which he labors and his diligence in the discharge of his duties cannot in law or sound reason depend in any degree upon his being or not being a member of a labor organization. It cannot be assumed that his fitness is assured, or his diligence increased, by such membership, or that he is less fit or less diligent because of his not being a member of such an organization. It is the employee as a man and not as a member of a labor organization who labors in the service of an interstate carrier. Will it be said that the provision in question had its origin in the apprehension, on the part of Congress, that if it did not show more consideration for members of labor organizations than for wage-earners who were not members of such organizations, or if it did not insert in the statute some such provision as the one here in question, members of labor organizations would, by illegal or violent measures, interrupt or impair the freedom of commerce among the States? We will not indulge in any such conjectures. . . .

Justice Joseph McKenna, writing in dissent, thought the majority was simply being dense. "[I]t is not necessary to suppose that labor organizations will violate the law," wrote the dissenting Justice. "Their power may be effectively exercised without violence or illegality. . . ."32 The Senate Committee had opined, McKenna noted, that "this bill, should it become law, would reduce to a minimum labor strikes which affect interstate commerce. . .."33 "A provision of law which will prevent or tend to prevent the stoppage of every wheel in every car of an entire railroad system," wrote McKenna, certainly concerned practices having a "direct influence on interstate commerce." ${ }^{34}$

Yet McKenna was careful to note the limits of his disagreement with the majority. ${ }^{35}$

I would not be misunderstood. I grant that there are rights which can have no material measure. There are rights which, when exercised in a private business, may not be disturbed or limited. With them we are not concerned. We are dealing with rights exercised in a quasi-public business and therefore subject to control in the interest of the public.

\footnotetext{
${ }^{31}$ Id at $178-79$.

${ }^{32}$ Id at 187.

${ }^{33} \mathrm{Id}$.

${ }^{34}$ Id at 189.

${ }^{35}$ Id at 190 (emphasis in original).
} 
McKenna was thus thinking about Section 10 in much the same way that Judge Cochran had. The common law contractual prerogatives of the employer were regulable at all only because the business concerned was affected with a public interest; the impact that the employer's exercise of those prerogatives exerted on interstate commerce provided the commercial police power rationale for their regulation. ${ }^{36}$

Despite the fact that the majority had disagreed with McKenna about the impact of an employer's labor policies on interstate commerce, both majority and minority had embraced a common analytical model. Though Harlan and his colleagues in the majority were almost willfully aguostic about the relationship between railroad labor relations and interstate commerce, they had forged an important connection between commerce clause jurisprudence and due process jurisprudence. The sphere of liberty of contract protected by the Fifth Amendment was now defined in terms of the impact that employer-employee relations exerted on interstate commerce. If the Court ever came to view those relations as exerting a direct effect on interstate commerce, the Fifth Amendment would no longer serve to insulate those relations from congressional regulation. Moreover, though the majority had expressed no opinion on the issue, McKenna had suggested that the employer's common law contractual prerogatives could be regulated only if his business was affected with a public interest. So as the category of businesses affected with a public interest expanded, the sphere of liberty protected by the Fifth Amendment would accordingly contract. Three areas of constitutional jurisprudence-liberty of contract, the concept of a business affected with a public interest, and the notion of what constituted a direct effect on interstate commerce-had thus become developmentally interdependent. ${ }^{37}$

An issue similar to that presented in Adair came before the Court in 1915. Coppage $v$ Kansas $^{38}$ concerned the constitutionality of a Kansas statute prohibiting employers from requiring their employees, as a condition of employment, to sigu yellow-dog contracts.

\footnotetext{
${ }^{36}$ Justice Holmes wrote a separate dissent, in which he argued, typically, that it was not unreasonable for Congress to assume that the provisions of Section 10 would advance the policy of preventing strikes tending to interrupt interstate commerce. 208 US at 190-92.

${ }^{37}$ On the consequences of interdoctrinal synergy for commerce clause doctrine, see Cushman, note 12 .

${ }^{38} 236$ US I (1915).
} 
A Mr. Hedges, a switchman for the St. Louis \& San Francisco Railway Company and a member of the Switchmen's Union of North America, had refused to sign a yellow-dog contract presented to him by his employer. Mr. T. B. Coppage, superintendent of the company (and apparently no relation to the O. B. Coppage of Adair), had accordingly discharged Mr. Hedges. Mr. Coppage was indicted and convicted under the Kansas statute, and appealed his conviction to the Supreme Court.

Justice Mahlon Pitney, who had voted for the Erdman Act in 1898 while a Congressman from Morristown, New Jersey, ${ }^{39}$ wrote the opinion of the Court declaring the statute unconstitutional. The Kansas statute, the Court held, was not distinguishable in principle from the federal statute reviewed in Adair. "Under constitutional freedom of contract," wrote Pitney, "whatever either party has the right to treat as sufficient ground for terminating the employment, where there is no stipulation on the subject, he has the right to provide against by insisting that a stipulation respecting it shall be a sine qua non of the inception of the employment, or of its continuance if it be terminable at will." 40

Because Coppage concerned a state statute, the commerce power could not be invoked to provide a police power rationale. The regulatory justification would accordingly have to be found within the conventional categories of the state's police power. "[W]hat possible relation," asked Pitney, did the statute have "to the public health, safety, morals or general welfare? None is suggested, and we are unable to conceive of any."41 The primary object of the statute was that of "leveling inequalities of fortune," 42 and this was not a recognized police power rationale.

Justice McKenna, who had dissented in Adair, demonstrated his fidelity to Adair's analytical model by joining the Coppage majority. Both cases had involved regulations of a business affected with a public interest. But in Coppage, unlike in Adair, there had been no police power rationale on which to justify the regulation of the employment contract.

\footnotetext{
${ }^{39} 31$ Cong Rec 5053 (55-2).

to 236 US at 13 (emphasis in original).

${ }^{41}$ Id at 16.

${ }^{42}$ Id at 18.
} 
Dissenting for himself and Justice Hughes, ${ }^{43}$ Justice Day chided the majority for not taking the associative rights of the workers seriously. "Would it be beyond the legitimate exercise of the police power," asked the dissenters, "to provide that an employee should not be required to agree, as a condition of employment, to forego affiliation with a particular political party, or the support of a particular candidate for office?"44 Might not the State prohibit an employer from requiring its employee to join or not to join a particular church? ${ }^{45}$ "It seems to me," wrote Justice Day, "that these questions answer themselves." $\$ 6$ "The law should be as zealous to protect the constitutional liberty of the employee as it is to guard that of the employer. A principal object of this statute is to protect the liberty of the citizen to make such lawful affiliations as he may desire with organizations of his choice. It should not be necessary to the protection of the liberty of one citizen that the same right in another citizen be abridged or destroyed." 47

A defense of the right to join a union cast in the rhetoric of freedom of association was not novel in 1915. In Commonwealth $v$ Hunt, ${ }^{48}$ decided in 1842, Chief Justice Lemuel Shaw of the Massachusetts Supreme Judicial Court had deployed similar associational language in his landmark opimion holding that labor unions were not per se criminal conspiracies. ${ }^{49}$ In upholding the right of the Boston Journeymen Bootmakers' Society to organize, Shaw sought to analogize unions to other common societies formed for purposes of mutual aid and protection. "Such an association," he wrote, "might be used to afford each other assistance in times of poverty,

${ }^{43}$ Holmes again dissented separately, arguing that Adair and Locbner ought to be overruled. 236 US at 26-27.

H 236 US at 37.

t5 Id at 39.

${ }^{46}$ Id at 37.

47 Id at 40 .

484 Met 111 (1842).

${ }^{49}$ Id at 129-31, 134. See Leon Fink, Labor, Liberty and tbe Law: Trade Unionism and the Problem of the American Constitutional Order, 74 J Am Hist 904, 910 (1987); A. Konefsky, "As Best to Subserve Their Own Interests": Lemuel Sbaw, Labor Conspiracy, and Fellow Servants, 7 Law \& Hist Rev 219 (1989); Levy, Tbe Law of tbe Commonwealth and Cbief Justice Sbaw 203 (Harvard Univ, 1957); Tomlins, The State and the Unions: Labor Relations, Law, and tbe Organized Labor Movement, 1880-1960, 42-44 (Cambridge Univ, 1985); Woodiwiss, Rights v. Conspiracy: A Sociological Esay on the History of Labour Law in the United States 58-61 (St. Martin's, 1990). 
sickness and distress; or to raise their intellectual, moral or social condition; or to make improvement in their art; or for other proper purposes." 50 The association's objective of recruiting all bootmakers into the society was not unlawful, Shaw held, for it would give to the union "a power which might be exerted for [such] useful and honorable purposes. ..." 51

Following Shaw's opinion in Hunt, American courts generally adhered to the view that the formation of labor associations for mutual aid and protection was perfectly legal. ${ }^{52}$ Indeed, throughout the balance of the nineteenth and twentieth centuries, American judges generally agreed that strikes to obtain higher wages, shorter hours, or better working conditions were lawful..$^{53}$ Shaw's view that strikes to obtain a closed shop were legal, however, was not so readily accepted by the American bench. Throughout the late nineteenth and early twentieth centuries, state and federal courts repeatedly held that strikes and boycotts designed to secure the employment of only union workers were unlawful. ${ }^{54}$ Such union actions were enjoinable, the courts held, for two reasons: first, they constituted coercive interferences with the right of the employer to run his business as he saw fit; and second, they aimed to require the non-union workingman to surrender a portion of his associational liberty as the price of plying his lawful trade.

\footnotetext{
s0 4 Met at 129.

${ }^{51}$ Id.

52 Indeed, some courts occasionally expressed the view that the formation of such associations was not only not criminal, but positively laudable. See, e.g., Coeur D'Alene Consolidated o Mining Co. v Miners' Union, 51 F 260, 263 (CCD Idaho 1892); State v Stewart, 9 A 559, 566 (Vt 1887).

${ }^{53}$ Arnold Paul, Conservative Crisis and tbe Rule of Law 106 (P Smith, 1976); Herbert Hovenkamp, Enterprise and American Law, 1836-1937 216, 226 (Harvard Univ, 1991).

${ }^{54}$ Id. Hovenkamp, supra at 233. See Coeur D'Alene Consolidated \& Mining Co. v Miners' Union of Wardner, 51 F 260 (CCD Idaho 1892); Casey v Cincinnati Typograpbical Union No. 3, 45 F 135 (SD Ohio 1891); Old Dominion Steamsbip Co. v McKenna, 30 F 48 (SDNY 1887); Bauscb Macbine Tool Co. v Hill, 231 Mass 30 (1918); Snow Iron Works v Cbadwick, 227 Mass 382, 116 NE 801 (1917); Martin v Francke, 227 Mass 272, 116 NE 404 (1917); Folsom v Lewwis, 208 Mass 336, 94 NE 316 (1911); Plant $v$ Woods, 176 Mass 492 (1900); Erdman v Mitchell, 207 Pa 79 (1903); State v Dyer, 67 Vt 690, 32 A 814 (1895); State v Stewart, 59 Vt 273, 9 A 559 (1887); State v Glidden, 55 Conn 46 (1887); State v Donaldson, 32 NJL 151 (1867). See also Kayser v Fitzgerald, 178 NYS 130 (1919); Kealey v Faulkner, 7 Ohio NP 49 (1907); Lucke $v$ Clotbing Cutters' Assembly, 77 Md 396, 26 A 505 (1893); Ernst, The Closed Sbop, the Proprietary Capitalist, and the Law, 1897-1915 in S. Jacoby, ed, Masters to Managers (1989). See also Commons \& Andrews, Principles of Labor Legislation 112-15 (Harper \& Bros, 1927), and cases there cited.
} 
In Plant $v$ Woods, ${ }^{55}$ the Supreme Judicial Court of Massachusetts condemned the defendant union's threats to strike and boycott employers employing certain non-union plaintiffs. "The purpose of these defendants," the court found, "was to force the plaintiffs to join the defendant association, and to that end they injured the plaintiffs in their business, and molested and disturbed them in their efforts to work at their trade." 56 The union men "had no right to force other persons to join them." ${ }^{157}$ The attempt by the defendants "to compel the [non-union men] against their will to join the association" was, the court held, "intolerable, and inconsistent with the spirit of our laws." 58

Erdman $v$ Mitchell $^{59}$ involved one closed-shop strike in a larger campaign "to drive every plumber in Philadelphia into the United Association of Journeyman Plumbers."60 In Erdman, the court found that the defendant union members, through a perfectly peaceful strike, "undertook, by intimidation of plaintiffs and their employers to coerce the plaintiffs into joining their organization."61 "By this conduct of defendants," the court noted, "plaintiffs have been unable to secure any steady employment at their trade, and will have to enter one of defendants' unions or leave the city." 62 Condemning the union's actions, the court accepted the plaintiff's contention that "an agreement by a number of persons that they will by threats of a strike deprive a mechanic of the right to work for others merely because he does not choose to join a particular union, is a conspiracy to commit an unlawful act, which conspiracy may be restrained."63 Erdman is of particular interest, because it was not a case of a court protecting the right of workers to remain non-union men. The plaintiffs in the case were actually members of another union, who wished to remain loyal to the association with which they had voluntarily affiliated.

ss 176 Mass 492 (1900).

${ }^{56}$ Id at 502.

${ }^{57}$ Id.

${ }^{58}$ Id.

$59207 \mathrm{~Pa} 79$ (1903).

${ }^{60}$ Id at 89.

${ }^{61} \mathrm{Id}$.

${ }^{62} \mathrm{Id}$.

${ }^{63}$ Id. 
In Casey $v$ Cincinnati Typographical Union, the court decried the boycott of a non-union newspaper as "an organized effort to force printers to come into the union, or be driven from their calling for want of employment." 64 The court in Old Dominion Steamsbip Co. $v$ McKenna stated the rule succinctly: "All combinations and associations designed to coerce workmen to become members, or to interfere with, obstruct, vex, or annoy them in working, or in obtaining work, because they are not members . . . are pro tanto illegal combinations or associations." 65

As these cases made clear, the rights of workers to associate together, even to strike, were legally protected; these rights simply could not be used as a means to coerce workers in the exercise of their right to freedom of association. In deploying associational rhetoric in the Coppage dissent, Day and Hughes were simply calling for symmetry in the protection of associational liberty. Granted that the employer's liberty of contract was generally constitutionally protected, the dissenters would have held, the state could constitutionally prohibit him from using his freedom of contract to coerce the employee into forgoing his associational liberty. "While this court should, within the limitations of the constitutional guaranty, protect the free right of contract, it is not less important that the State be given the right to exert its legislative authority, if it deems best to do so, for the protection of rights which inhere in the privileges of the citizen of every free country."

At the core of the disagreement between the majority and the dissent lay a difference over whether the employee's agreement not to join a union was the product of coercion. The majority was able to resolve the tension between liberty of contract and freedom of association by finding simply that the employee had voluntarily contracted away this associational right. To the majority justices, there was no coercion involved. ${ }^{67}$ The dissenters could not accept this voluntary waiver theory; indeed, they seemed prepared to take judicial notice that such a waiver would always be the product of coercion. Day and Hughes saw the inequality of bargaining power between employer and employee as rendering the employment re-

\footnotetext{
64 45 F 135, 143 (SD Ohio 1891).

${ }^{65} 30 \mathrm{~F} \mathrm{48,} 50$ (SDNY 1887) (emphasis in original).

${ }^{66}$ Coppage v Kansas, 236 US 1, 40 (1915).

${ }^{67}$ Id at 8-9, 14-16, 20-21.
} 
lationship inherently subject to coercive abuse. The yellow-dog contract was for them coercive per se. ${ }^{68}$

Yet the majority was not taking the position that economic pressure exerted in the employment context could not constitute coercion. Less than three years following the Coppage decision, the Court would enjoin an effort by the United Mine Workers to unionize a non-union mine. ${ }^{69}$ All of the employees of the Hitchman Coal \& Coke Company had signed yellow-dog contracts. An agent of the U.M.W. proceeded secretly to persuade employees of the company to agree to join the union. The plan was that, once a sufficient number of employees had agreed to do so, they would quit in a body, join the union, and refuse to return to work unless the company consented to a closed-shop agreement with the U.M.W.

The Court enjoined the U.M.W.'s actions as an unlawful attempt to induce the employees to breach their contracts with the company. The Court further made it clear that it was troubled by "misrepresentations, deceptive statements, and threats of pecuniary loss" made by the union representative to the company's employees, as well as by the history of violence associated with coal strikes. ${ }^{70}$ But the Court also repeatedly condemned threats to strike for a closed-shop agreement as "coercive" of the employer and of the employees who had chosen not to join the union. ${ }^{71}$ The objective of such a strike, the Court stated, would be "to coerce the employer and the remaining miners to 'orgamize the mine,' that is, to make an agreement that none but members of the Union should be employed. . .."72 "The same liberty which enables men to form unions, and through the union to enter into agreements with employers willing to agree, entitles other men to remain independent of the union. . .."

In dissent, Justice Brandeis criticized the asymmetry presented by the Coppage and Hitchman decisions. "If it is coercion to threaten to strike unless [the employer] consents to a closed union shop, it

\footnotetext{
${ }^{63}$ Id at $32,35,38-42$.

${ }^{6}$ Hitcbman Coal \& Coke Co. $v$ Mitcbell, 245 US 229 (1917).

${ }^{30}$ Id at 258-59.

"Id at $248,250-51,253,255,258-59,261$.

72 Id at 255.

${ }^{73}$ Id at 251.
} 
is coercion also to threaten not to give one employment unless the [employee] will consent to a closed non-union shop. The employer may sign the union agreement for fear that labor may not be otherwise available; the workman may sign the individual agreement for fear that employment may not otherwise be obtainable." ${ }^{74}$ As Brandeis was not-so-obliquely suggesting, the fact that the Court (and the American judiciary generally) simultaneously embraced the view that a strike for a closed shop was coercive while the exaction of a yellow-dog contract was not ${ }^{75}$ seemed the rankest anti-union hypocrisy.

Perhaps it was. The majority may have remained troubled by the reputation for violence and syndicalism that had become associated with unionism as a result of the events of Haymarket Square, Homestead, the "Debs Rebellion," and other similar instances. ${ }^{76}$ Yet the majority's view that yellow-dog contracts were not coercive may not have seemed as preposterous in 1915 as it appears from the vantage point of the late twentieth century. As Herbert Hovenkamp has recently noted, America suffered throughout the nineteenth century from severe shortages of labor. In part as results of such shortages, slavery persisted in the United States long after it had disappeared in other Western nations; American entrepreneurs led the world in the development of labor-saving technology; America maintained virtually an open immigration policy; and the United States experienced significantly less labor unrest than contemporary England. Wages in the United States rose steadily throughout the nineteenth and early twentieth centuries, and wages and working conditions for American laborers were generally far better than those obtained by European workers. ${ }^{77}$

\footnotetext{
${ }^{74}$ Id at 271 (emphasis in original). Justice Brandeis actually concluded that neither the strike to obtain a closed-shop nor a yellow-dog contract implied "coercion in a legal sense." Id.

${ }^{75}$ For a discussion of the near-unanimity of state court decisions holding anti-yellow-dog contract statutes unconstitutional, see Coppage $v$ Kansas, 236 US at 21-26. It should be noted that not all states condemned strikes to obtain a closed shop. In those states, of course, the asymmetry criticized by Brandeis was not present. See Sayre, Criminal Conspiracy, 35 Harv L Rev 393, 407-8, n 49 (1922).

${ }^{76}$ See Paul, Conservative Crisis and tbe Rule of Law (cited in note 53). The stronger claim that the Court was anti-worker would be harder to sustain. For example, in 1917, the year Hitcbman was decided, the Court upheld an Oregon law limiting the working day for men to ten hours. Bunting v Oregon, 243 US 426 (1917).

${ }^{77}$ Hovenkamp, Labor Conspiracies in American Law, 1880-1930, 66 Tex L Rev 919, 930 (1988).
} 
In light of these historical consequences of the labor shortage, argues Hovenkamp, political economists writing in the early twentieth century "perceived the bargaining positions of capital and labor as more or less equal. Indeed, they felt that the advantage, if any, lay with labor. ... They argued that it was labor and not employers that could make take-it-or-leave-it offers."78

Illustrative of the view that laborers could avail themselves of a veritable smorgasbord of employment options was the opinion of the Georgia Supreme Court in Western \& Atlantic R.R. Co. v Bishop. ${ }^{79}$ In $B$ ishop, an employee of the railroad had in his employment contract waived his statutory right to recover against the company for injuries occasioned by the negligence of his fellow servant. Subsequently injured by a fellow employee, Bishop sought to have the waiver set aside on the grounds that it violated public policy. Bishop relied heavily on the U.S. Supreme Court decision in Railroad Company $v$ Lockwood, ${ }^{80}$ which had held void as against public policy a contract exempting a common carrier from liability for damage to freight or passengers caused by the negligence of the carrier or its servants. Distinguishing Lockwood, the Georgia court held that the carrier stood in a monopolistic relation to the passenger or shipper, and its contractual prerogatives could be regulated for that reason. In relation to its employee, however, the railroad held no such monopoly. Upholding the contractual waiver, the court held that the railroad was "only one of a million of employers with whom [Bishop] might have sought employment."

The massive waves of immigration to the United States in the late nineteenth and early twentieth centuries may have helped somewhat to ameliorate the perception of labor shortage that undoubtedly lay behind the Georgia court's seemingly hyperbolic remarks. Between 1886 and 1916, nearly 19 million immigrants arrived in the United States. ${ }^{82}$ Yet wage rates continued to rise significantly, especially in the years leading up to the Coppage decision. Despite nearly flat growth in the 1890 s, real wages in the

\footnotetext{
${ }^{78}$ Id at 930-31. Hovenkamp offers this observation as a means of explaining why earlytwentieth-century courts and politieal economists were inclined to treat labor combinations as analogous to, rather than different from, business combinations.

$750 \mathrm{Ga} 465$ (1874).

${ }^{80} 17$ Wall 375 (1873).

${ }^{81} 50 \mathrm{Ga}$ at 472 .

${ }^{82}$ Ellis Hawley, Tbe Great War and tbe Searcb for a Modern Order 11-12 (New York, 1979).
} 
United States rose 37 percent between 1890 and $1914 .{ }^{83}$ This occurred despite the fact that not even 8 percent of the American labor force was unionized at any time before $1914 .{ }^{84}$ The productive capacity of the American economy appeared to be more than adequate to absorb the flood of new immigrants. ${ }^{85}$ Indeed, the lot of the American worker seemed to be getting consistently better rather than worse. ${ }^{86}$ The existence of some unemployment was acknowledged, but was frequently attributed to laziness or other defects of character. ${ }^{87}$ In 1907 , the year in which the Hitcbman case was commenced, the nationwide unemployment rate was 2.8 percent ${ }^{88}$ in 1917 , the year of the Court's decision, the national rate was only 4.6 percent. ${ }^{89}$ There was little reason to think that the remote panhandle of West Virginia harbored a large untapped reservoir of labor. As Justice Pitney wrote for the majority, "[i]t was one thing for [the company] to find, from time to time, comparatively small numbers of men to take vacant places in a going mine, another and a much more difficult thing to find a complete gang of new men to start up a mine shut down by a strike. . .."90

Though the Court probably did not have access to some of these

\footnotetext{
${ }^{83}$ Stuart Bruchey, Tbe Wealtb of the Nation 138 (Harper \& Row, 1988).

${ }^{84}$ Id at 137.

${ }^{85}$ Between 1901 and 1913 the nationwide unemployment rate in the manufacturing and transportation sectors rose above 7 percent only twice, in the recession years of 1904 and 1908. In all other years, the rate was below 6 percent; in seven of those thirteen years, the rate was 4 percent or lower. Commons et al, 3 History of Labor in tbe United States 128 (Macmillan, 1935). The nationwide unemployment rate for the entire civilian workforce during those years rose above 6 percent only twice, in 1908 and 1911. In all other years, the rate was below 6 percent; in five of those thirteen years, the rate was 4 percent or lower. Stanley Lebergott, Manpower in Economic Growtb: Tbe American Record Since 1800 43-47, 512 (New York, 1964). The average national unemployment rate for all civilian workers in the decade 1900-1909 was 4 percent; for the decade 1910-1919, the figure was 5 percent. Id at 189.

${ }^{86}$ Dubofsky, Industrialism and tbe American Worker, 1865-1920, 119 (H. Davidson, 1985).

${ }^{87}$ Commons et al, note 85, at 115; John Garraty, Unemployment in History 113-18 (Harper \& Row, 1979); Lebergott, note 85, at 166; Roy Lubove, The Struggle for Social Security 147 (Harvard Univ, 1968).

${ }^{88}$ Lebergott, note 85 , at 512 .

${ }^{89}$ Id. The rate for the manufacturing and transportation sectors in each of those years was 3.5 percent. Commons et al, note 85 , at 128 . Moreover, at least some of this unemployment was probably attributable to factors having little to do with the size of the labor supply: inability to work during certain months of the year due to weather conditions, which particularly afflicted the nation's large population of agricultural workers; a lack of paid vacations to absorb seasonal declines in demand; and perhaps in some regions a higher incidence of worker illness than we experience today. Lebergott, note 85, at 165-71.
}

${ }^{90}$ Hitcbman Coal \& Coke Co. v Mitcbell, 245 US 229, 258 (1917). 
specific statistics on wages and employment, the Justices undoubtedly entertained at least an impressionistic understanding of their import. In his opinion striking down the District of Columbia minimum wage law in Adkins $v$ Cbildren's Hospital, ${ }^{91}$ Justice Sutherland remarked: "[w]e cannot close our eyes to the notorious fact that earnings everywhere in all occupations have increased-not alone in States where the minimum wage law obtains but in the country generally. . .."92 Reasoning in the idiom of Adam Smith, many legal minds must have continued to believe that the growth in demand for labor had exceeded the growth in supply. A judge who had grown to maturity in the labor-short nineteenth century might well have thought that the American laborer in 1915 was actually bargaining from a position of some strength. ${ }^{93}$ To be sure, individual laborers and employers often did not bargain from equal positions of strength-even in times of low unemployment-and the Coppage majority recognized this. ${ }^{94}$ But these disparities in bargaining power were not in the majority's view so great as to render the labor contract the product of coercion. As they saw it, the laborer wishing to retain his freedom to associate with a union could always find another employer to bargain with. Recognizing the structure of the labor market and the perceived ease of employee mobility, ${ }^{95}$ an employer in a labor-hungry market was in no position to "coerce" his employee into contracting away his associational freedom. But an employer struck for a closed shop was frequently in no position to bargain with a non-umion man.

If such a view was problematic in 1915 , it was to become increasingly implausible. The demobilization of the armed forces following World War I, coupled with the tremendous influx of European immigrants in 1919 and 1920, caused fears of widespread unemployment. ${ }^{96}$ Indeed, 1921's unemployment rates of 21.2 percent in the manufacturing and transportation sectors marked the highest rate in decades. ${ }^{97}$ President Harding brought together a Commis-

\footnotetext{
${ }^{91} 261$ US 525 (1923).

92 Id at 560 .

${ }^{93}$ Hovenkamp, note 77, at 931.

${ }^{44}$ Coppage v Kansas 236 US 1, 17 (1915).

${ }^{95}$ Hovenkamp, note 77 , at 931 .

${ }^{96}$ Parmet, Labor and Immigration in Industrial America 169-90 (Twayne, 1981).

${ }^{97}$ Commons et al, note 85 , at 128 . The nationwide civilian unemployment rate of 11.7 percent was the highest since 1898 . Lebergott, note 85 , at 43,512 .
} 
sion on Unemployment in 1921, and attempts to alleviate the problem through state unemployment insurance programs began in earnest. ${ }^{98}$ The AFL again renewed its long-standing campaign for immigration restriction. Some business interests predictably contended that there was a labor shortage, but few were persuaded. In 1921 and again in 1924, a Republican-controlled Congress and White House enacted and signed legislation placing substantial restrictions on immigration. ${ }^{99}$ Despite this contrived contraction of the labor market, the subsequent onset of the Great Depression brought sustained unemployment in numbers previously unimaginable. ${ }^{100}$

The cases condemning strikes for a closed shop demonstrated that the courts were prepared to see coercion in economic pressure exerted by one of the parties to the employment relationship. As the Hitchman case illustrated, the meaning of the term "coercion" was not so constricted that the Court could not have found that an employee was coerced into signing a yellow-dog contract. There was no need for the Court to expand its notion of coercion to include pressure brought to bear from a superior bargaining position. In order to arrive at the conclusion that yellow-dog contracts were coercive, however, the Court would have to change its assumptions about the relative bargaining strengths of employers and employees. Changes in the structure of the labor market between 1915 and the 1930s would prompt a re-examination of those assumptions.

Yet in 1915 Day and Hughes were not contending that the employment relationship was inherently coercive and therefore regulable in all its aspects. ${ }^{101}$ The dissenters were instead suggesting that there were certain valuable rights of association to which liberty of contract ought to give way. Indeed, it was the nature of the right compromised that appears to have led them to the conclu-

\footnotetext{
${ }^{93}$ Lubove, note 87 , at ch 7.
}

99 Parmet, note 96, at 169-90.

${ }^{100}$ In 1932, more than 13 million adult men were unemployed. Leuchtenburg, Franklin D. Roosevelt and the New Deal 1 (Harper \& Row, 1963). In 1933, fully 25 percent of the labor force was unemployed. Bruchey, note 83, at 157-58. In the decade of 1930-1939, the average national unemployment rate was 18 percent. Lebergott, note 85, at 189 .

${ }^{101}$ For an early analysis of the concept of coercion in the employment relationship and other contexts, see Hale, Coercion and Distribution in a Supposedly Non-Coercive State, 38 Pol Sci Q 470 (1923). 
sion that the bargain was coerced. Day's analogies between yellowdog contracts and contracts promising not to join a particular church, political party, or other "such lawful affiliations" were of course designed to reduce the majority's position to absurdity. But by implying that the majority would have decided cases involving such hypothetical contracts differently, the dissenters were also accusing the majority of according labor unions second-class status as voluntary associations. As one historian has put it, "American labor organizations lived in a legal twilight zone, expressions of an associational impulse growing in society at large, yet differentiated from other expressions of that impulse by society's law. . .."102

In 1915, only Day, Holmes, and Hughes were prepared to reach across that twilight zone to assimilate unionism to liberalism's traditional solicitude for voluntary association. In 1930, however, Hughes would return from a fourteen-year hiatus in his judicial career to lead a reconstituted Court. During his tenure as Chief Justice, the accommodation between contractual and associational liberty for which he and Justice Day had contended would be struck.

\section{Wartime Lessons and a New Profile for ORganized LABOR}

As the country confronted the exigencies of domestic production, commumication, and transportation brought on by World War I, it became clear that the Adair majority's professed agnosticism on the relationship between union-management relations and interstate commerce was no longer tenable. It was now "essential to the national safety that the volume of production be maintained at the highest possible level, and that the avenues of communication and transportation remain always open." ${ }^{103}$ It was recognized that industrial strife would tend to frustrate the implementation of these critical objectives. Accordingly, the National War Labor Board was established in April of 1918 for the purpose of ensuring the peaceful and prompt settlement of labor disputes in vital war industries. ${ }^{104}$

102 Tomlins, note 49, at 33.

${ }^{103}$ Joel Seidman, Tbe Yellow Dog Contract 25 (Johns Hopkins, 1932).

${ }^{104}$ Id; Valerie Jean Conner, The National War Labor Board, ch 2 (Univ North Carolina, 1983); Pringle, Tbe Life and Times of William Howard Taft 915 (Farrar \& Rinehart, 1939). 
President Wilson appointed to the co-chairmanship of the Board former President William Howard Taft. Taft, a former judge on the United States Court of Appeals, a professor at Yale Law School, and a future Chief Justice of the United States, was perhaps the most prominent conservative lawyer of the day, and was widely expected to be a pro-employer member of the Board. But, as Taft's biographer reports, the future Chief Justice found his experience on the Board to be personally transformative. An extended trip to the munitions and textile mills of the South convinced $T$ aft of the need for the establishment of minimum wages. This conviction was duly reflected in the orders of the Board, and subsequently in Taft's dissent in Adkins $v$ Cbildren's Hospital. ${ }^{105}$

Taft and his fellow Board members also recognized that industrial peace was necessary to the uninterrupted production and transportation of the goods needed for the successful prosecution of the war. To this end the Board announced that (1) "The right of workers to organize in trade unions and to bargain collectively, through chosen representatives, is recognized. This right shall not be denied, abridged, or interfered with by the employers in any manner whatsoever"; and (2) "Employers shall not discharge workers for membership in trade unions, nor for legitimate trade union activities."106 The Board ordered numerous reinstatements with back pay for employees discharged for engaging in legitimate union activities; prohibited employers from requiring employees to sign yellow-dog contracts; and forbade employers to require their employees to join company unions. ${ }^{107}$ Indeed, the Board ordered employers to discontinue the use of yellow-dog contracts in cases involving General Electric, Smith \& Wesson, and the Omaha and Council Bluffs Street Railway Company. ${ }^{108}$ The war had temporarily transformed businesses that were ordinarily purely private into businesses affected with a national public interest and consequently

${ }^{105}$ Conner, supra; Pringle, supra, at 916, 918.

${ }^{106}$ US Bureau of Labor Statistics, National War Labor Board, Bulletin No 287, 30-34 (1922), quoted in Philip Taft, Collective Bargaining Before the New Deal, in Harry A. Millis, ed, How Collective Bargaining Works 901-2 (New York, 1942); Presidential proclamation, April 8, 1918, cited in Pringle, The Life and Times of William Howard Taft at 917-18 (cited in note 104).

${ }^{107}$ Conner, The National War Labor Board (cited in note 104); Philip Taft, supra, at 902.

${ }^{108}$ Conner, note 104, at ch 7; Daniel Ernst, Tbe Yellow Dog Contract and Liberal Reform, 1917-1932, 30 Labor History 251, 254 (1989); Pringle, note 104, at 921; Seidman, note 103, at 25; Edwin Witte, The Government in Labor Disputes 222 (McGraw-Hill, 1932). 
subject to a greater degree of regulation. ${ }^{109}$ And the National War Labor Board, headed up by a leading conservative and the next Chief Justice, had taken judicial notice of the fact that an employer's interference with his employees' legitimate associational activities could impede the capacity of such a business to perform its crucial public function. ${ }^{110}$

The years following World War I also brought increasing solicitude for the associational rights of the nation's workers. This may well have been a by-product of changing perceptions about the nature of labor umions. At the turn of the century, Christopher Tomlins has noted, the leadership of the American labor movement had embraced trade unionism as a means to achieve larger, radical political goals. Through association, Samuel Gompers had explained, "the workers would come to know that 'the state is by rights theirs' and would thereupon take over the functions of government "in the interests of all." "111 Collective bargaining was "an entering wedge toward industrial democracy and abolition of the profit system," the end result of which would be "full labor control" of industry. 112

Over the course of the next twenty years, however, the AFL sloughed off "its old associational ideology for a redefined voluntarism which drastically downplayed the radical political connotations of associationalism." 113 Instead of a means to "accomplish the transformation of prevailing political and social institutions," "[v]oluntary association and collective bargaining became mechanisms for the improvement of material conditions within the political and industrial framework of the new corporate economy."114 By World War I, Tomlins argues, "this ideology was manifest

${ }^{109}$ See Block $v$ Hirsh, 256 US 135, 155 (1921).

${ }^{110}$ See David Brody, The American Worker in the Progressive Age: A Comprebensive Analysis, in Brody, Workers in Industrial America 42 (Oxford Univ, 1980); Brody, The Emergence of Mass Production Unionism, in Braenan et al, eds, Cbange and Continuity in Twentietb Century America 243 (Ohio Univ, 1964).

111 Tomlins, note 49 , at 74 ; see also id at 54-59.

112 Id, quoting Robert F. Hoxie in Trade Unionism in the United States 274-75 (D. Appleton, 1923); Forbath, note 7, at 800-817.

113 Tomlins, note 49 , at 77 .

${ }^{114}$ Id at 74-75; see David Brody, The Expansion of the American Labor Movement: Institutional Sources of Stimulus and Restraint, in Brody, ed, The American Labor Movement 121 (Harper \& Row, 1971); Samuel Gompers, Labor and tbe Employer 286 (Arno, 1920). 
in virtually all of the AFL leadership's actions."115 Rather than conceptualizing themselves as corporative bodies seeking to absorb the functions of the state, AFL unions now saw themselves as individual entities pursuing their own legitimate self-interests within the state's common law contractualist paradigm. "Organized workers, they argued, were freely associating citizens who ought to enjoy the same freedoms of action and expression that individual workers and citizens enjoyed. . . . In Gompers's hands, the AFL model was a labor version of the kind of business-based associationalism that elite reformers like Herbert Hoover and organizations like the National Civic Federation advocated during the first decades of the new century." 116 In addition, the AFL sought to refurbish its public image "by providing a model of the good worker/ citizen that was essentially the same as that to be found in the literature of the middle-class, Progressive movement. The worker was intelligent, responsible, civic-minded, thrifty, self-reliant, tolerant of other people's religions, and patriotic. . . ."117

The liberalization of the AFL was accompanied by two other major developments in the history of labor unions. First, as the result of a wave of prosecutions initiated during and in the wake of World War I, the syndicalist Industrial Workers of the World was virtually defunct by the early $1920 \mathrm{~s}^{118}$ Second, the years following World War I also saw the relationship between the Socialist Party and the nation's workers grow increasingly attenuated. By 1921 , membership in the Party had dwindled to $13,000{ }^{119}$ By 1928 , membership had fallen to under 8,000 , and the party had become "increasingly an organization of ministers and intellectuals rather than industrial workers." 120 "The labor movement of the 1920's," Tomlins concludes, "was a loose and disaggregated combination of individual organizations, not the quasi-syndicalist associa-

\footnotetext{
115 Tomlins, note 49 , at 77 .

${ }^{116}$ William Forbath, Law and the Sbaping of the American Labor Movement 147 (Harvard Univ, 1991).

${ }^{117}$ Anthony Woodiwiss, Rights v. Conspiracy, note 49, at 139; see Sweeney, The A.F.L.'s Good Citizen, 1920-1940, 13 Labor History (1972).

${ }^{118}$ Joseph Rayback, A History of American Labor 282, 289-90 (Macmillan, 1968); see Conlin, Bread and Roses, Too (Greenwood, 1969); Melvyn Dubofsky, We Sball be All: A History of the Industrial Workers of the World (Quadrangle, 1969).

${ }^{119}$ Hawley, note 82, at 130 .

${ }^{120}$ Id at 131.
} 
tion of self-governing trades established in 1886. As such, its reconciliation to the prevailing common law tradition was no longer problematic." 121 In other words, unions had come increasingly to be seen as liberal institutions.

These changes in the complexion of the labor movement made defenses of unions cast in the rhetoric of liberal rights discourse increasingly resonant. Indeed, the growing recognition of the associational legitimacy of unions was widely expressed in the critique of yellow-dog contracts that flourished in the 1920s. Opponents of the contract "repeatedly depicted the agreement as an illiberal institution, which snatched from workers their rights of free association, speech, and thought."122 The yellow-dog contract, argned one Illinois labor leader, violated the workers' rights of free association, "the essential difference between the free man and the slave." 123 Such contracts were "a plain denial of the right of association," wrote Felix Frankfurter and Nathan Greene. ${ }^{124}$ Echoing Justice Day's Coppage dissent, Edwin Witte wrote: "would anyone tolerate for a nioment aid by the courts to employers in the enforcement . . . of promises which they may exact from their employees not to join the Methodist Church or the Masons, or any other religious or fraternal organization?" 125 Cornelius Cochrane, a persistent critic of the contract for the American Labor Legislation Review, likewise echoed Justice Day's critique. "Union labor," he wrote, "is convinced that if employers insisted upon employees signing a contract that they would not vote the Republican or Democratic ticket, or attend the Protestant or Catholic Church, or join the Knights of Columbus or the Masons, there would be an immediate public outcry against this invasion of the right of voluntary association." 126 "[U]nless we are permanently to overthrow the American principle that organization into voluntary societies is to be encouraged rather than strangled," Cochrane contended, "the

121 Tomlins, note 49, at 91; see William Forbath, note 116, at 128-35.

122 Ernst, note 108 , at 263.

${ }^{123} \mathrm{Id}$.

${ }^{124}$ Frankfurter and Greene, Congresional Power Over the Labor Injunction, 31 Colo L Rev 385, 396 (1931).

${ }^{125}$ Edwin Witte, "Yellow Dog" Contracts, 6 Wis L Rev 21, 31 (1930).

${ }^{126}$ Cochrane, Why Organized Labor is Figbting "Yellow Dog" Contracts, 15 Am Lab Legis Rev 227, 232 (1925). 
'yellow dog' contract must be declared illegal."127 A study of labor relations in the coal industry undertaken by the United States Coal Commission in 1922 and 1923 resulted in a scathing denunciation of the contract. "A manager," stated the Commission's report, "who can mine coal only with the use of spies, intimidation, and forced contracts, which aim to destroy the freedom of will of his workers, is not much of a manager and less of a man."128

By the late 1920s the New York courts were refusing to enforce yellow-dog contracts on the grounds that they were void for lack of mutuality. ${ }^{129}$ Emboldened by the trend, Wisconsin passed a statute in 1929 declaring yellow-dog contracts void and unenforceable as opposed to public policy; Arizona, Colorado, Ohio, and Oregon followed suit two years later. ${ }^{130}$ And in 1930 the Senate rejected the nomination of John J. Parker to the Supreme Court largely because Parker had upheld the validity of yellow-dog contracts in the Red Jacket Coal case. ${ }^{131}$ Even Parker's Senate supporters vigorously denounced the yellow-dog contract, and called for its statutory abolition. ${ }^{132}$ Of the ten Senators who spoke in defense of Parker's nomination, only one suggested that the contract was legitimate. $^{133}$

${ }^{127}$ Cochrane, "Yellow Dog" Abolished in Wisconsin, 19 Am Lab Legis Rev 315, 316 (1929).

${ }^{128}$ Seidman, note 103, at 31-32.

${ }^{129}$ See Interborough Rapid Transit Co. $v$ Lavin, 247 NY 65, 159 NE 863 (1928); Excbange Bakery and Restaurant, Inc. $v$ Rifkin, 245 NY 260, 157 NE 130 (1927); Interborough Rapid Transit Co. $v$ Green, 131 Misc 682, 227 NYS 258 (1928); Carey and Oliphant, The Present Status of the Hitchman Case, 29 Colum L Rev 441 (1929); Cochrane, Branding "Yellow Dog" Contracts, 18 Am Lab Legis Rev 115 (1928); Witte, "Yellow Dog" Contracts (cited in note 125).

${ }^{130}$ Irving Bernstein, Tbe Lean Years 394, 411 (Houghton Mifflin, 1960); Cochrane, "Yellow Dog" Abolisbed in Wisconsin (cited in note 127); Witte, note 108, at 228; Seidman, note 103, at 35. The proliferation of state anti-yellow-dog statutes continued throughout the 1930s. See Fraenkel, Recent Statutes Affecting Labor Injunctions and "Yellow Dog" Contracts, 30 Ill L Rev 854, 858-59 (1936). Many of these statutes sought to preserve associational liberty by prohibiting not only yellow-dog contracts, but agreements requiring the employee to join a union as well. Id at 859, n 29.

${ }^{131}$ United Mine Workers $v$ Red Jacket Consolidated Coal \& Coke Co., 18 F2d 839 (CCA 4th, 1927), cert denied, 275 US 536 (1927); Irving Bernstein, note 130, at 406-9; Cochrane, Public Opinion Flays Judicial Approval of "Yellow Dog" Contracts, 20 Am Lab Legis Rev 181 (1930).

${ }^{132}$ Irving Bernstein, note 130 , at 407.

${ }^{133}$ Ernst, note 108, at 255; Seidman, note 103, at 36; see Peter Graham Fish, Red Jacket Revisited: The Case That Unraveled Jobn J. Parker's Supreme Court Appointment, 5 Law \& History Rev 51-104 (1987). 


\section{The Railway Labor Act and Texas \& New Orleans Railroad Co. v Brotherhood of Railway Clerks}

The Court was not again confronted with the kinds of constitutional issues presented in Adair and Coppage until Hughes had returned to lead the Court in 1930, when Texas \& New Orleans Railroad Co. $v$ Brotberbood of Railway and Steamship Clerks ${ }^{134}$ presented the constitutionality of Section 2 of the Railway Labor Act of 1926. ${ }^{135}$ The pertinent provision stated: "Representatives, for the purposes of this Act, shall be designated by the respective parties . . . without interference, influence or coercion exercised by either party over the self-organization or designation of representatives by the other."136 The Railroad had previously recognized the Brotherhood, but had, in the wake of a dispute over wages, sought to organize its own company union of railway clerks, and "endeavored to intimidate members of the Brotherhood and to coerce them to withdraw from it and to make [the company union] their representative in dealing with the Railroad Company." 137 The district court issued a temporary injunction ordering the Railroad and its agents to cease "interfering with, influencing, intimidating, or coercing" any of the clerks in their "free and untrammeled right of self-organization." 138 The Railroad nevertheless proceeded to recognize the company union, and not the Brotherhood, as the legitimate representative of its clerical employees. The district court subsequently found the Railroad in contempt of its earlier order. The Court directed the Railroad to purge itself of contempt by (1) disestablishing the company union, (2) reinstating the Brotherhood as the representative of its clerical employees, and (3) reinstating certain employees who had been discharged by the Railroad for participating in lawful union activities. ${ }^{139}$ The temporary injunction was subsequently made permanent, and a motion to vacate

\footnotetext{
134281 US 548 (1930).

13544 Stat 577 , ch 347 .

136 Id.

137281 US at 555.

${ }^{138}$ The text of the temporary injunction is reproduced at $281 \mathrm{US}$ at $555-56, \mathrm{n} 1$.

139281 US at 557.
} 
the order in the contempt proceedings was denied. ${ }^{140}$ The Circuit Court of Appeals affirmed the decree, and the Supreme Court granted a writ of certiorari. ${ }^{141}$

In the congressional debates over the Railway Labor Act, which had set up a system for the voluntary arbitration of disputes between the railroads and their employees, Section 2 had been uncontroversial. Members of both Houses of Congress had repeatedly justified the provisions of the bill by observing that railroads were businesses affected with a public interest and that the public had an interest in the continuous and uninterrupted flow of commerce. ${ }^{142}$ Adair and Coppage had twice been cited in the context of a debate over whether the ICC could constitutionally set aside a wage agreement between a railroad and a union. ${ }^{143}$ No one, however, had suggested that those cases rendered Section 2 constitutionally infirm.

Predictably, the brief for the Texas and New Orleans Railroad did. The Railroad contended that all of its actions, including the discharge of its employees, were constitutionally protected. Relying principally on Adair and Coppage, the Railroad asserted that its agents $^{144}$

had an inherent constitutional right even to make membership in [the company union] a condition to the continuation of employment. Certainly this includes the lesser right to peaceably, without threats, influence employees to join [the company union], and to recognize [the company union] as the only organization through which they would confer and negotiate with their employees. . . . [T] he defendants had the constitutional right to refuse to confer or negotiate with any organization at all, which includes the right to confer and negotiate only in a particular manner.

${ }^{140}$ Brotberbood of Railway and Steamsbip Clerks, et al. $v$ Texas \& N.O.R. Co. et al., 25 F2d 873 (SD Texas 1928); Brotberbood of Railway and Steamship Clerks, et al. v Texas \& N.O.R. Co. et al., 25 F2d 876 (SD Texas 1928).

${ }^{141}$ Texas \& N.O.R. Co. et al. $v$ Brotberbood of Railway and Steamsbip Clerks et al., 33 F2d 13 (5th Cir 1929); Texas of N.O.R. Co. et al. v Brotberbood of Railway and Steamsbip Clerks et al., 280 US 550 (1929).

${ }^{142} 67$ Cong $\operatorname{Rec} 4507,4519,4648,4669,8815,9048 ; \mathrm{S} \operatorname{Rep} 606(69-1)$ at 2-3; H Rep 328 $(69-1)$ at 6.

${ }^{143} 67$ Cong Rec 8817, 8893.

${ }^{14}$ Brief for the Petitioner at 86, Texas \& N.O.R. Co., 281 US 548 (emphasis in original). 
The federal government, the Railroad contended, could not constitutionally require an employer "to retain in his service an unwanted employee, or . . . to deal or not to deal with certain groups of his employees." ${ }^{45}$ Nor could the commerce power supply the police power rationale for regulating the employer's constitutional prerogatives. Railway labor organizations were not in 1930, any more than they had been when Adair was decided, "so definitely connected with interstate commerce that Congress may require the employer to deal or not to deal with them in certain ways."146 "If the evils existing in 1898 [the year of the Erdman Act's enactment] after the great strike [the Pullman strike of 1894] were not sufficient to authorize a much milder interference with the relations of employer and employee," argued the Railroad, "it is difficult to see how conditions have so changed as to authorize an even greater interference when conditions have changed, if at all, for the better." 147

On the brief for the Brotherhood was the Chicago-based attorney for the Railway Employees' Department of the AFL, Donald Richberg. Richberg, who would one day replace Hugh Johnson as the head of the National Recovery Administration, was a co-author of what would become the Norris-LaGuardia Act, and the principal architect of the Railway Labor Act. ${ }^{148}$ Richberg's extensive experience dealing with the constitutional dimensions of labor law made him singularly qualified to defend the Act before the Court. ${ }^{149}$

Richberg's principal task was to provide the analytic link that the majority had found missing in Adair-the connection between membership in a labor organization and interstate commerce. Richberg's strategy was to recount the lessons learned during and in the wake of World War I. In Wilson $v$ New ${ }^{150}$ decided in 1917, the Court had held that it was within the emergency war power

\footnotetext{
${ }^{1+5}$ Id at 93.

${ }^{146} \mathrm{Id}$.

${ }^{147}$ Id at 93-94.

${ }^{148}$ Ernst, note 108, at 267, 271-73; Peter Irons, note 4, at 29.

${ }^{149}$ See Thomas E. Vadney, The Wayward Liberal: A Political Biograpby of Donald Ricbberg (Univ Kentucky, 1970).

${ }^{150} 243$ US 332 (1917).
} 
of the federal government to prescribe wages for railway employees in a case in which a railroad and its employees' union could not reach an agreement concerning wages. The Court had held that the government might "exert the legislative will for the purpose of settling the disputes, and bind both parties to the duty of acceptance and compliance, to the end that no individual dispute or difference might bring ruin to the vast interests concerned in the movement of interstate commerce." The government must have, the Court had held, the "power to remedy a situation created by a dispute between employers and employees as to rate of wages, which, if not remedied, would leave the public helpless." The extreme step of wage fixing had admittedly been taken in a time of emergency which no longer obtained; but the Court had nevertheless recognized the impact that a dispute between management and organized labor might exert on interstate commerce. ${ }^{151}$

In the wake of World War I, Richberg noted, Congress had enacted Title III of the Transportation Act of 1920. The Act had created the Railroad Labor Board, which was designed to settle labor-management disputes that threatened to interrupt interstate commerce. The railway employees were to be represented before the Board by representatives of their various labor organizations. Therefore, argued Richberg, the Act had "created an imperative legal recognition of a very definite legal connection between membership in a labor organization and the carrying on of interstate commerce." 152

The Railway Labor Act similarly "expressed a public policy to adopt as the means of preventing interruptions of interstate commerce, and therefore, as the means of a most necessary regulation of interstate commerce, the encouragement of collective bargaining between carriers and their employees. . .." "Thus," concluded Richberg, "the questioning of the majority opinion in the Adair case-as to the 'legal or logical connection $* * *$ between an employee's membership in a labor organization and the carrying on of interstate commerce'-is completely answered. The connection is now both legal and logical."153

${ }^{151}$ Brief for the Respondent at 93-94, Texas \& N.O.R. Co., 281 US 548.

152 Brief for the Respondent at 86-87, Texas \& N.O.R. Co., 281 US 548. On the politics and legislative history of the Transportation Act of 1920, see K. Austin Kerr, American Railroad Politics, 1914-1920 (Univ Pittsburgh, 1968).

${ }^{153}$ Brief for the Respondent at 92-93, Texas \& N.O.R. Co., 280 US 550. 
Having offered up the commercial police power rationale for the regulation, Richberg next sought to minimize the law's intrusion on the employer's liberty of contract, to emphasize its protection of the employees' freedom of association, and to note the public nature of the railroad's business. In making his argument, Richberg glossed over the fact that the Railroad had been found in contempt for discharging some of its union employees, and that in order to have purged itself of contempt it would have been required to reinstate them. Richberg rather contended that the Railway Labor Act, unlike the Erdman Act, did not "make it a crime for an employer to hire whom he pleases, or discharge whom he pleases. The Act does not attempt to limit his power of hiring or discharge. The Act provides only that those who are his employees shall have the right to desiguate their own representatives to negotiate with him concerming terms and conditions of employment. . . . It must be apparent that there is not in issue in the present case the basis of the decision in the Adair case, that is, the right of the employer to hire whom he pleases." 154

The "minor restraint here sought upon the employer's liberty of contract," 155 Richberg contended, ought to be indulged in order to protect the fundamental rights of its employees. "[T]he right of employees to associate themselves together (which is, of course, an inherent right under our form of government), should be protected as a 'legitimate object for the exercise of the police power." "156 And why were the associational rights of these employees a fit subject for the protection of the police power? Because "[r]ailway employees are 'charged by law' with public duties, and by Act of Congress their organizations have been charged with most important public duties." 157

Richberg had now pressed all of the requisite analytic buttons. The common law prerogatives of the employer were subject to police power regulation because the business in which he was engaged was affected with a public interest. The wartime experience had made clear that the connection between labor-management relations and interstate commerce was sufficiently close to provide

\footnotetext{
${ }^{154}$ Id at 89-90 (emphasis in original).

155 Id at 101-2.

${ }^{156}$ Id at 93.

157 Id (emphasis in original).
} 
the rationale for invocation of the commercial police power. And with respect to such businesses affected with a public interest, the legislature could constitutionally truncate the employer's common law prerogatives in order to protect employees in their exercise of legitimate rights of association.

A unanimous Supreme Court (Justice McReynolds did not participate) thought that the constitutionality of the Act was not even a close question. 158 "We entertain no doubt of the constitutional authority of Congress to enact the prohibition," wrote Chief Justice Charles Evans Hughes. Hughes gave short shrift to arguments that had carried the day in Adair. Indeed, the dismissal of Adair's contention that there was no nexus between membership in a labor organization and the free flow of interstate commerce merited no more than two sentences. "Congress," the Court held, "may facilitate the amicable settlement of disputes which threaten the service of the necessary agencies of interstate transportation. In shaping its legislation to this end, Congress was entitled to take cognizance of actual conditions and to address itself to practicable measures." 159

The Court likewise demonstrated its willingness to take cognizance of actual conditions. The Railroad's promotion and subsidy of the company union and its discharge of the Brotherhood's leaders, the Court found, constituted "interference, influence or coercion" of its employees with respect to their rights to selforganization. ${ }^{160}$ Such terms were now held to mean "pressure, the use of the authority or power of either party to induce action by the other . . the abuse of relation or opportunity so as to corrupt or override the will. . . ." ${ }^{\prime 61}$ Because the threat of lost employment coerced the employees in their freedom to determine which (if any) labor association they might wish to join, their decision to join the company union could not be seen as a voluntary waiver of their right to associate with some other organization. The Railroad was

\footnotetext{
${ }^{158}$ The unanimity of the Court was readily obtained. Justice Van Devanter, who had voted with the majority in Coppage, wrote Chief Justice Hughes that he considered the opinion "as near perfect as is humanly possible." Pusey, 2 Cbarles Evans Hugbes 713 (Macmillan, 1951).

${ }^{159}$ Texas of N.O.R. Co. et al. v Brotberbood of Railway and Steamsbip Clerks et al., 281 US $548,570(1930)$.

${ }^{160} \mathrm{Id}$ at 560 .

${ }^{161}$ Id at 568.
} 
using its contractual prerogatives as a means of depriving its employees of their freedom of association. Because the decision to join the company union was recharacterized as coerced rather than voluntary, the resolution of the conflict between liberty of contract and freedom of association effected by the Coppage majority was no longer available. Having abandoned Pitney's voluntary waiver theory, the Court would have to find some other reconciliation of the conflict between contractual and associational liberty.

For the first time, the Court resolved the conflict in favor of associational freedom. When these two competing liberal ideals of liberalism came into conflict, the Court held, liberty of contract would have to be recede so that freedom of association might be preserved. Accordingly, the Court held, Section 2 of the Railway Labor Act constituted a legitimate protection of employees' right of free association. ${ }^{162}$

The legality of collective action on the part of the employees in order to safeguard their proper interests is not to be disputed. It has long been recognized that employees are entitled to organize for the purpose of securing the redress of grievances and to promote agreements with employers relating to rates of pay and conditions of work. Congress was not required to ignore this right of the employees but could safeguard it. . . Thus the prohibition by Congress of interference with the selection of representatives for the purpose of negotiation and conference between employers and employees, instead of being an invasion of the constitutional right of either, was based on the recognition of the rights of both.

Such a characterization of the Court's reconciliation of the conflict of rights was less than forthcoming; and Hughes's prestidigital performance was far from over. Glossing over, as had Richberg, the fact that the district court's orders enforcing the Act had required the Railroad to reinstate employees it had discharged, Hughes dismissed Adair and Coppage as "inapplicable."

The Railway Labor Act of 1926 does not interfere with the normal exercise of the right of the carrier to select its employees or to discharge them. The statute is not aimed at this right of the employers but at the interference with the right of employees to have representatives of their own choosing. As the carri-

${ }^{162}$ Id.

${ }^{163}$ Id at 571. 
ers subject to the Act have no constitutional right to interfere with the freedom of the employees in making their selections, they cannot complain of the statute on constitutional grounds.

This was a distinction that could be remembered just long enough to be stated once; ${ }^{164}$ and there were at the time and have been since several commentators who wondered whether, after 1930, there was anything left of Adair and Coppage. ${ }^{165}$ Just how much of those cases was left, to which of the Justices, and for what reasons, would not be clear until 1937.

\section{The Luxuriation of the Associational Rationale}

Congress was quickly alert to the possibilities offered by the Texas or New Orleans case, and was sensitive to the associational language employed in Hughes's opinion. ${ }^{166}$ Section 3 of the NorrisLaGuardia Act, enacted in 1932, declared that yellow-dog contracts were contrary to the public policy of the United States and would henceforth be unenforceable in the federal courts. ${ }^{167} \mathrm{Mem}-$ bers of both Houses repeatedly invoked the authority of the Texas $\&$ New Orleans case in support of this provision, and persistently declared that yellow-dog contracts deprived employees of their freedom of association. ${ }^{168}$ "It would not be tolerated for a moment," argued Wisconsin Senator Blaine, echoing the words of Justice

\footnotetext{
164 Paul Freund, Charles Evans Hughes as Cbief Justice, 81 Harv L Rev 4, 35 (1967).

${ }^{165}$ Seidman, note 103, at 35, n 109; Berman, The Supreme Court Interprets the Railway Labor Act, 20 Am Econ Rev 619 (1930); Richard Cortner, The Jones \$r Laugblin Case 22 (Knopf, 1970); B. C. Gavit, The Commerce Clatse of the United States Constitution 231-33 (Principia, 1932); Thomas R. Fisher, Industrial Disputes and Federal Legislation 170, n 21 (New York, 1940); Comment, 37 W Va L Q 101 (1930); Comment, 40 Yale L J 92 (1930); Comment, 25 Ill L Rev 307 (1930); Samuel Hendel, Charles Evans Hughes and the Supreme Court 228, 260 (Kings Crown, 1951); see Fraenkel, Recent Statutes Affecting Labor Injunctions and Yellow Dog Contracts, 30 Ill L Rev 854, 862, n 46 (1936). One commentator opined that the Texas \& New Orleans decision "would seem to bring [the Courtl still closer to complete realization that 'liberty to contract' may mean a liberty to join voluntary associations of workmen unhindered by the 'yellow dog' contract." Comment, 81 U Pa L Rev 68, 73 (1932). For a perceptive contemporary understanding of the limited implications of the Texas \& New Orleans decision, see Johns, The Validity of Federal Labor Legislation with Special Empbasis Upon the National Labor Relations Act, 20 Marq L Rev 57, 70-71 (1936).

${ }^{166}$ See Comment, 30 Ill L Rev 884, 904 (1936) (Texas \& New Orleans decision "recognize[d] the power of Congress to preserve the right of freedom of association of employees").

16747 Stat 70 , ch $90(72-1)$.

16875 Cong $\operatorname{Rec} 4503,4504,4626-28,4677,4762,4917,5463,5469$; S Rep 163 (72-1) at 11-14; H Rep 669 (72-1) at 7. See Witte, The Federal Anti-Injunction Act, 16 Minn L Rev 638,655 (1932).
} 
Day's Coppage dissent, "if employers compelled all their employees to sign contracts that they would not belong to some lodge or to some particular church, or that they will vote the Republican ticket. . . ."169 But if employers could require employees to sign yellow-dog contracts, argued Blaine, they could prevent their employees from "doing anything, either in or out of working hours, that they do not like."170

The seriousness with which this associational rationale was taken was reflected in a disagreement between the House and Senate over the bill's declaration of policy. The version of the bill passed by the House provided in part ${ }^{171}$

Sec. 2. ... Whereas ... the individual unorganized worker is commonly helpless to exercise actual liberty of contract and to protect his freedom of labor ... wherefore it is necessary that he have full freedom of association [to organize and select representatives, etc.]"

The Senate version of the bill's declaration of policy inserted, between "wherefore" and "it is necessary," the phrase, "though he should be free to decline to associate with his fellows."172 The House initially balked at the Senate's amendment; ${ }^{173}$ but the Senate, whose members nearly unanimously supported the antiyellow-dog provision, insisted on its pristine formulation of the worker's associational liberty. ${ }^{174}$ In the final version of the bill, the Senate's amendment prevailed. ${ }^{175}$ As one commentator noted, "[t]he freedom of association of workers and of employers alike is held to be a necessity in order to foster freedom of contract."176

Senator Norris scored another victory for associational liberty the following year when Congress enacted the Bankruptcy Act of 1933. ${ }^{177}$ Shortly before the close of the legislative session, Norris

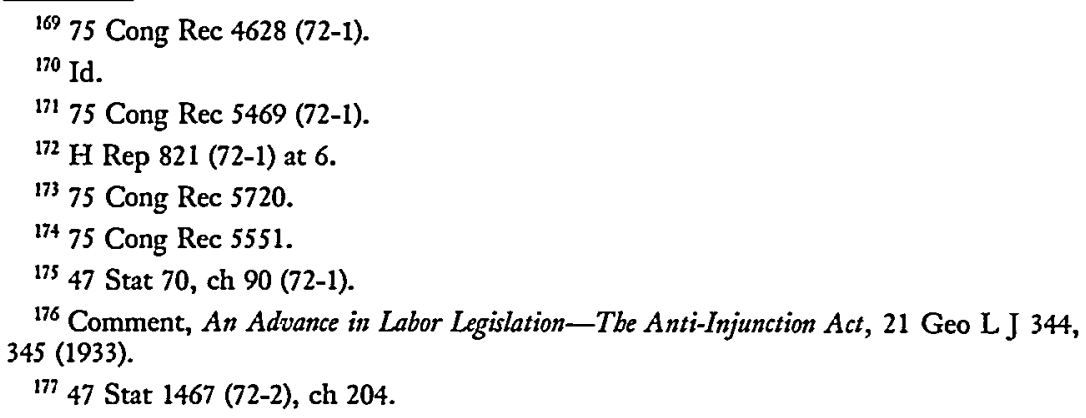


succeeded in persuading the Senate to amend the House version of the bill, adding what were to become Sections $77(\mathrm{p})$ and $(\mathrm{q}) .{ }^{178}$ Section $77(\mathrm{p})$ provided: ${ }^{179}$

No judge or trustee acting under this Act shall deny or in any way question the right of employees on the property under his jurisdiction to join the labor organization of their choice, and it shall be unlawful for any judge, trustee or receiver to interfere in any way with the organizations of employees, or to use the funds of the railroad under his jurisdiction, in maintaining so-called company unions, or to influence or coerce employees in an effort to induce them to join or remain members of such company unions.

Section 77 (q) provided: "No judge, trustee, or receiver acting under this Act shall require any person seeking employment on the property under his jurisdiction to sign any contract or agreement promising to join or to refuse to join a labor organization," and required the judge, trustee, or receiver in question to discard any such contract in force before the subject property came under his jurisdiction. ${ }^{180}$

Defending his amendment on the Senate floor, Norris emphasized the fact that the worker's associational liberty would be thereby preserved. "It [the amendment] permits rather than compels men to join a so-called company union, to join whatever union they want to that they shall be free men, and that they shall not have that freedom taken away from them by any action of the receiver or by any order of the court."181 As Irving Bernstein noted, Norris's amendment "outlawed both the yellow-dog contract and the closed shop."182 This symmetrical protection of workers' associational liberty was again embraced by the Emergency Railroad Transportation Act of 1933, whose Section 7 (e) incorporated by reference Sections 77 (p) and (q) of the Bankruptcy Act. ${ }^{183}$

${ }^{178} 76$ Cong Rec 5118-22 (72-2). The House agreed to the amendment at 76 Cong Rec $5360(72-2)$.

${ }^{179} 47$ Stat $1467,1481(72-2)$.

18047 Stat $1467,1481$.

18176 Cong Rec 5119 (72-2).

${ }^{182}$ Bernstein, The New Deal Collective Bargaining Policy 44 (Univ California, 1950).

${ }^{183} 48$ Stat 211,214 (73-1), ch 91. See Bernstein, note 182, at 44-46. Norris and his colleagues contemporaneously sought to protect workers' freedom of association through Section 7(a) of the National Industrial Recovery Act ("NIRA"), the precursor of the Wagner Act. Donald Richberg was again the principal author. R. W. Fleming, The Significance of the 
Similarly revealing were the debates over the 1934 amendments to the Railway Labor Act. The amendments created a new Section 2, which set out the "general purposes" of the Act. Among these purposes was "to forbid any limitation upon freedom of association among employees or any denial, as a condition of employment or otherwise, of the right of employees to join a labor organization."184 And indeed, the backers of the bill mobilized associational rhetoric in its support. ${ }^{185}$ But the House and Senate differed on the form these associational protections should take. The original House bill prohibited employers from influencing, coercing, or requiring their employees to join company unions. ${ }^{186}$ The Senate version prohibited employers from influencing, coercing, or requiring their employees to join any labor organization whatsoever. ${ }^{187}$ The Senate again insisted on its symmetrical formulation, and the House, adequately assured that the Senate's version prohibited company unions, again capitulated. ${ }^{188}$ Once again, Congress had sought to safeguard workers' associational liberty by outlawing both the yellow-dog contract and the closed shop. ${ }^{189}$

Thus in four major pieces of legislation enacted in the early 1930s, Congress had evinced a preoccupation with symmetrical protections for the worker's freedom of association. The employer could not require the employee to agree not to join a union, nor could he discharge him for joining one. Neither could the employer seek to influence or coerce the employee into joining a company union. Finally, the eniployer could not, at his employee's union's

Wagner Act, in Derber \& Young, eds, Labor and tbe New Deal 126 (Da Capo, 1972). Section 7(a) required that every code of fair competition propounded pursuant to the NIRA provide: (1) that employees be free to organize to bargain collectively free from employer interference or coercion; and (2) "that no employee and no one seeking employment shall be required as a condition of employment to join any company union or to refrain from joining, organizing, or assisting a labor organization of his own choosing." 48 Stat 195, 198-99, ch 90 (73-1). The Act's aberrationally permissive posture regarding the closed shop was in large measure the quid pro quo for the AFL's acceptance of the trade association provisions sponsored by the Chamber of Commerce. Irving Bernstein, The Turbulent Years 32 (Houghton Mifflin, 1969). With both business and orgamized labor happy to have more room to maneuver than conventional antitrust law might have permitted, the freedom of non-union workers not to associate with a labor organization got lost in the shuffle.

${ }^{184} \mathrm{H} \operatorname{Rep} 1944(73-2)$ at 5.

${ }^{185}$ H Rep 1944 (73-2) at 1-2; 78 Cong Rec 11717, 11720, 12553-12555.

${ }^{186} \mathrm{H} \operatorname{Rep} 1194(73-2)$ at 6.

18778 Cong Rec 12550.

18878 Cong Rec 12553-12555.

${ }^{189}$ Irving Bernstein, The Turbulent Years at 212 (cited in note 183). 
behest or otherwise, seek to influence or coerce any of his employees into joining a noncompany union. In the discrete areas of industry covered by these acts, the asymmetry of the Coppage era appeared to be rectified. With the passage of the Wagner Act the next year, however, this preoccupation with symmetry would be abandoned, and the asymmetry of the yellow-dog period would be turned on its head.

\section{Virginian Railway Co. v System Federation, No. 40}

The constitutionality of the amended Railway Labor Act was attacked before the Court in 1937. The dispute arose over attempts by the Railway to avoid collective bargaining with the Federation, which was the duly accredited representative of the Railway's mechanical department ("back-shop") employees. The district court's decree had directed the Railway (1) to "treat with" the Federation and to "exert every reasonable effort to make and maintain agreements concerning rates of pay, rules and working conditions . . ."; (2) not to enter into "any contract, undertaking, or agreement of whatsoever kind concerning rules, rates of pay or working conditions affecting its Mechanical Department employees, . . . except . . . with the Federation"; and (3) not to interfere with, influence, or coerce its employees with respect to their free choice of representatives, nor, for such purposes, to organize or foster any company union. ${ }^{190}$ As the Court's opinion noted, the Railway did not argue that the third part of the district court's order was unconstitutional. In view of the decision in the Texas \& New Orleans case, noted the Court, "[t]hat contention is not open to it."191

The Railway did, however, challenge the other two portions of the lower court's order, and it did so on two fronts. The Railway clearly could not claim that it was not a business affected with a public interest-the business in which it was engaged was paradigmatically public. But the Adair case had also involved a business affected with a public interest, and the Railway could rely on the absolutist language in which Justice Harlan had described the employer's liberty of contract. Glossing over the fact that the Railway

\footnotetext{
${ }^{190}$ Virginian Railway Co. v System Federation, No. 40, 300 US 515, 538-41 (1937).

${ }^{191}$ Id at $543-44$.
} 
was engaged in a public business, attorney for the Railway James Piper told the Court that "the freedom of contract argument is that it is our right to refuse business negotiations with anyone." 192 The Railway further argued that the back-shop employees were engaged in the purely intrastate activities of repair and manufacture, neither of which was sufficiently related to the interstate activities of the Railway to admit of federal regulation. Because the activities of the back-shop employees were beyond the reach of the federal commerce power, the impact of those activities on interstate commerce could not supply the commercial police power rationale for regulating the Railway's liberty of contract. ${ }^{193}$

The Act and the lower court's decree were defended by the Federation and by the United States, which filed a brief as amicus curiae. "The Railway Labor Act," argued the brief for the Federation, "does not require a carrier to enter into any contract, but merely that it shall negotiate with regard to the matter. . . Negotiations are not contracts, and in and of themselves cannot have the effect of bringing into existence contractual rights or duties."194 "The petitioner is not placed under a duty to enter into a particular agreement, to agree upon particular terms, or to make any contract whatsoever," argued the brief for the United States. ${ }^{195}$ "One who confers, unlike one who contracts, is not bound as to any future conduct. His future freedom is not thereby restrained."196

This nuch was true. But the defenders of the Act also had to justify that portion of the lower court's order that had restrained the Railway from entering into any contract concerning rates of pay, rules, and conditions with anyone other that the Federation. That portion of the decree, noted the brief for the United States, did not restrain the Railway "in the normal exercise of its right to select or discharge its employees." 197 But to the extent that the decree did impose limitations on the Railway's liberty of contract, observed the Federation's brief, it was important to bear in mind

\footnotetext{
${ }^{192}$ Arguments in Cases Arising Under Labor Acts Before tbe Supreme Court, Sen Doc 52 (75-1), at 13-14 [hereinafter cited as Arguments].

${ }^{193}$ Brief for the Petitioner at 38-47, Virginian Railway Co., 300 US 515.

${ }^{194}$ Brief for the Respondent at 48-49, Virginian Railway Co., 300 US 515.

${ }^{195}$ Brief for the United States at 82, Virginian Railway Co., 300 US 515 (emphasis in original).

196 Id at 84.

197 Id at 89.
} 
that the Railway was "a common carrier, a public utility, the operator of a business peculiarly charged with the public interest. Its business may, therefore, be regulated to a greater extend [sic] than is the case with other industries without infringing upon the constitutional guarantee of freedom of contract."198

There remained only the task of articulating the police power rationale for the regulation. The congressional power to regulate commerce could reach the activities of back-shop employees, argued the brief for the United States, even though such employees were not themselves engaged in interstate commerce. The Texas \& New Orleans case had upheld the validity of the Act as applied to clerks, whose work was clearly intrastate in nature. A strike by the Railway's back-shop employees would "both endanger the safety of interstate transportation and directly obstruct its movement." Moreover, any dispute between the Railway and its back-shop employees would likely be communicated to Railway employees engaged in interstate commerce, thereby further threatening the continuity of interstate transportation. ${ }^{199}$ The purpose of the Act, argued the Federation, was "to aid and encourage the railroads and their employees to make and maintain agreements to the end that labor strife and discontent be allayed and labor harmony and good morale prevail; all to the end that there be no interruption of commerce in the public interest. ${ }^{200}$ The means employed by the Act were, the Federation contended, reasonably related to that legitimate end. ${ }^{201}$

The litigants were given a foreshadowing of the Court's decision when Justice Sutherland interrupted the Railway counsel's freedom of contract argument to inquire, "[d]o you attach any importance to the fact that the railroad company is engaged in a business charged with the public interest?"202 Piper's reply was a convoluted "no," and counsel for both the Federation and the United States were sure to emphasize the Railway's public nature in their presentations. ${ }^{203}$ "Does the Fifth Amendment," asked counsel for the

${ }^{198}$ Brief for the Respondent at 55-56, Virginian Railway Co., 300 US 515; see also id at 57,63 .

${ }^{199}$ Brief for the United States at 7, Virginian Railway Co., 300 US 515.

${ }^{200}$ Brief for the Respondent at 52, Virginian Railway Co., 300 US 515.

201 Id.

202 Arguments, note 192, at 13.

${ }^{203}$ Id at $32,39-40$. 
United States, "prevent the Congress from infringing somewhat upon the absolute right to be perfectly free in the operation of your business and in your dealings with your employees in order to assure continuous operation of the railroad systems-a great public necessity . . . ?"204 Citing Nebbia $v$ New York ${ }^{205}$ for the proposition that due process requires "only that the law shall not be unreasonable, arbitrary, or capricious, and that the means selected shall have a real and substantial relation to the object sought to be obtained," counsel concluded that "the slight interference [here involved] with the personal liberty of the railroad management . . . seems a very minimum that they could be asked to relinquish in order that we may bring about industrial peace." 206

The opinion of the Court, delivered March 29, was unanimous. Employing again the analytical model initially embraced in Adair, the Court noted that each of the doctrinal prerequisites to regulation of the employment relationship had been satisfied. First, the court noted, the business of the railroad was clearly affected with a public interest. "More is involved," wrote Justice Stone, "than the settlement of a private controversy without appreciable consequences to the public. The peaceable settlement of labor controversies, especially where they may impair the ability of an interstate carrier to perform its service to the public, is a matter of public concern." 207

The Court nevertheless sought to minimize the extent of the intrusion on the employer's common law prerogatives. Neither the Act nor the decree required the Railway to enter into any agreement, held the Court-the Railway was merely required to "treat with" the Federation, not to contract with it. ${ }^{208}$ Moreover, the portion of the decree restraining the Railway from entering into a collective agreement with anyone other than the Federation did not prevent the Railway from refusing to enter into any collective contract and instead negotiating contracts with its employees on an individual basis. ${ }^{209}$ Because the provisions of the Act did not " interfere with the normal exercise of the right of the carrier to

\footnotetext{
204 Id at 39.

205291 US 502 (1934).

${ }^{206}$ Arguments, note 192, at 39-40.

${ }^{207}$ Virginian Railway Co. $v$ System Federation, No. 40, 300 US 515, 552 (1937).

${ }^{208}$ Id at $557,559$.

${ }^{209}$ Id at 548-49, 557, 559.
} 
select its employees or to discharge them," "Adair and Coppage had "no present application." 10

Finally, Justice Stone articulated the commercial police power rationale undergirding the instant application of the Act. A strike by the Railway's employees, he wrote, "if more than temporary, would seriously cripple [the Railway's] interstate transportation. ${ }^{211}$ The means prescribed by the Act were reasonably related to the legitimate end of preventing such interruptions of commerce. The Act was therefore a legitimate exercise of the federal government's commercial police power. ${ }^{212}$

\section{The Impact of Nebbia v New York}

Early in 1934, before the enactment of either the Wagner Act or the amendments to the Railway Labor Act, the Supreme Court handed down a decision that would have profound repercussions for liberty of contract jurisprudence. Yet Nebbia $v$ New York ${ }^{213}$ did not concern any regulation of the employment relationship. Instead, it involved a New York State Control Board regulation of retail milk prices. The regulation was an attempt to ameliorate the effects of cutthroat competition in the retail milk business, where price-cutting had reduced the income of dairy farmers to a level below the cost of production. Leo Nebbia, a retailer convicted of selling milk below the price prescribed by State regulation, argued that the regulation deprived him of property without due process of law in violation of the Fourteenth Amendment. Price regulation, Nebbia contended, was constitutional only as applied to a business affected with a public interest. For a business to be affected with a public interest, he argued, it had to be either a public utility or a natural monopoly. Because neither Nebbia's business itself nor the milk industry as a whole belonged to either of these categories, Nebbia contended, his business was not affected with a public interest and therefore was not subject to price regulation. ${ }^{214}$

The Court, by a vote of five to four (the Four Horsemen-

\footnotetext{
${ }^{210}$ Id at 559.

211 Id at 556.

212 Id at 553-57.

213291 US 502 (1934).

214 Id at 531.
} 
directly and those that affected such commerce only indirectly. ${ }^{217}$ Only activities that affected commerce "directly" were subject to federal regulation. ${ }^{218}$ Activities that affected interstate commerce only "indirectly" - such as local sales, mining, agriculture, and manufacturing-were subject only to state regulation. The Tenth Amendment forbade federal regulation of such activities. ${ }^{219}$

However, if an otherwise "local" activity was deemed to be part of a continuous "current" of interstate commerce, that activity might be subjected to federal regulation. On the basis of this "current of commerce" doctrine, the Supreme Court had upheld federal statutes regulating transactions in the nation's major stockyards and grain exchanges. ${ }^{220}$ In each instance goods had been shipped from one state to another, where they paused for a local activity, and then moved on to yet another state. The pause for the local activity was not deemed to break the "current" of interstate commerce of which it was a part.

Justices committed to the maintenance of dual federalism ${ }^{221}$ recoguized that, in an economy becoming increasingly integrated on a national scale, there was virtually no end to the list of business activities that could be conceived as located in a current of interstate commerce. If the traditional regulatory prerogatives of the states were to be preserved, some means would have to be found to restrict the scope of the current of commerce doctrine. The means settled on by the Court was ingenious. Conflating the direct/indirect distinction of commerce clause jurisprudence with the public/ private distinction of due process jurisprudence, the Court consistently found that only businesses affected with a public interest could be located in a federally regulable current of interstate commerce. A business affected with a public interest had the power to affect commerce directly; a purely private business did not. The current of commerce was thus conceived as a sequence of interstate

\footnotetext{
${ }^{217}$ See Corwin, Commerce Power versus States Rights 189-208 (Princeton Univ, 1936).

${ }^{218}$ See id at $198-208$.

${ }^{219}$ See id at 189-93; Carter $v$ Carter Coal Co., 298 US 238 (1936); United States $v$ Butler, 297 US 1 (1936).
}

${ }^{220}$ Compare Swift \& Co. $v$ United States, 196 US 375 (1905); Stafford $v$ Wallace, 258 US 495 (1922); Cbicago Board of Trade v Olsen, 262 US 1 (1923); Tagg Bros. \& Moorbead v United States, 280 US 420 (1930) with Hopkins $v$ United States, 171 US 578 (1898). See Cushman, note 12.

${ }^{221}$ See Corwin, note 11 , at ch 1 . 
McReynolds, Sutherland, Van Devanter, and Butler-dissenting), rejected Nebbia's contentions, and in so doing effectively retired the distinction between public and private enterprise. "[T]here is no closed class or category of businesses affected with a public interest," wrote Justice Roberts for the majority. "The phrase, 'affected with a public interest' can, in the nature of things, mean no more than that an industry, for adequate reason, is subject to control for the public good."215

So far as the requirement of due process is concerned, and in the absence of other constitutional restriction, a state is free to adopt whatever economic policy may reasonably be deemed to promote public welfare, and to enforce that policy by legislation adapted to its purpose. . . . If the laws passed are seen to have a reasonable relation to a proper legislative purpose, and are neither arbitrary nor discriminatory, the requirements of due process are satisfied. ... The Constitution does not secure to anyone liberty to conduct his business in such fashion as to inflict injury upon the public at large, or upon any substantial group of the people. Price control, like any other form of regulation, is unconstitutional only if arbitrary, discriminatory, or demonstrably irrelevant to the policy the legislature is free to adopt. . . . ${ }^{216}$

Nebbia's dismantling of the public/private distinction was a milestone in American constitutional development, and its ramifications for national collective bargaining legislation were twofold. First, the category "business affected with a public interest" would no longer operate as an independent constraint on legislative power to regulate the employment relationship. So long as the legislation was not patently arbitrary or capricious, the legislature could regulate the employment relations of any business, irrespective of whether it had in the past been considered a business affected with a public interest.

Second, due to an interdoctrinal relationship formed in the area of commerce clause doctrine, Nebbia augmented the category of enterprises whose employment relations might be deemed to affect interstate commerce directly. From the late nineteenth century through the mid-1930s, the Court had conscientiously maintained a distinction between activities that affected interstate commerce

\footnotetext{
215 Id at 536.

${ }^{216}$ Id at $537-39$.
} 
business activities connected by intrastate business activities affected with a public interest. As long as the class of businesses affected with a public interest had remained small and select, the channel cut by the current of commerce had remained narrow. ${ }^{222}$

Nebbia, however, had thrown the class of businesses affected with a public interest wide open. The internal logic of the current of commerce doctrine thus impelled the Court toward recognition of a broader conception of the current of commerce. Nebbia made it possible to conceptualize what had previously been considered purely private businesses as businesses affected with a public interest. This in turn made it possible to locate such business activities in a current of interstate commerce. These business activities could now be seen to have the capacity to affect interstate commerce directly. And because these businesses could now be seen as standing astride a current of interstate commerce, the impact that a disruption in their labor relations might exert on the flow of that current could provide the commercial police power rationale for federal regulation of the employer's liberty of contract. ${ }^{223}$

The dissenting Four Horsemen, however, had balked at the Court's abandonment of the formalist public/private distinction in due process jurisprudence. As a corollary, they were not committed to the consequences Nebbia implied for current of commerce jurisprudence. The intellectual structure of this Nebbian split would be reflected in the pattern of decision in the Wagner Act cases.

\section{The Wagner Act Cases}

Capping off the flurry of labor legislation enacted in the 1930s was the National Labor Relations Act, otherwise known as the Wagner Act. ${ }^{224}$ Section 7 of the Act secured to employees "the right to self-organization, to form, join, or assist labor organizations, to bargain collectively through representatives of their own choosing, and to engage in concerted activities, for the purpose of collective bargaining or other mutual aid or protection."225

\footnotetext{
222 Cushman, note 12 , at 114-24.

${ }^{223}$ Id at 130-31.

22449 Stat 449 (74-1), ch 372.

22549 Stat 449,452 .
} 
Section 8 described certain "unfair labor practices" in which employers were forbidden to engage. Sections 8(1) and 8(2) sought, as had their statutory predecessors, to preserve workers' freedom of association. Section 8(1) forbade the employer "to interfere with, restrain, or coerce employees in the exercise of the rights guaranteed in section 7."226 Section 8(2) sought to preserve employer neutrality among unions and to outlaw company unions by forbidding any employer "[t]o dominate or interfere with the formation or administration of any labor organization or contribute financial or other support to it." ${ }^{227}$ Section 8(3) constituted a frontal assault on Adair and Coppage, and a bet that the Texas \& New Orleans case had overruled them. Resurrecting in substance Section 10 of the Erdman Act, Section 8(3) forbade any employer "[b]y discrimination in regard to hire or tenure of employment or any term or condition of employment to encourage or discourage menbership in any labor organization."228 Section 8 thus clearly proscribed the nemeses of labor associationalism: anti-union discrimination in hiring and firing, company unions, and yellow-dog contracts. ${ }^{229}$

In the hearings and debates on the bill, opponents relied heavily on Adair and Coppage as precedents standing for the proposition that Section 8 violated the Fourteenth Amendment. ${ }^{230}$ Proponents of the bill, however, contended that those precedents were no longer applicable. "The power of Congress to guarantee freedom of organization, to prohibit the company-dominated union, and to prevent employers from requiring membership or nonmembership in any union has been upheld completely" in the Texas \& New Orleans case, declared Senator Wagner. "[W]e cannot doubt that Coppage v. Kansas and Adair v. U.S. have been overruled."231 Time

\footnotetext{
${ }^{226} \mathrm{Id}$.

${ }^{227} \mathrm{Id}$.

${ }^{228} \mathrm{Id}$.
}

${ }^{229}$ See Thomas R. Fisher, Industrial Disputes and Federal Legislation 273 (New York, 1940).

${ }^{230}$ See, e.g., remarks of Sen. Hastings, 2 Legislative History of tbe National Labor Relations Act 2403-11 (Government Printing Office, 1949) [hereinafter cited as NLRB, Legislative History]; Statement of James A. Emery, Hearings before the Senate Committee on Education and Labor on S 1958 (74-1) at 854, reprinted in NLRB, Legislative History at 2240.

231 Statement of Senator Wagner, Hearings before the Senate Committee on Education and Labor on S 1958 (74-1) at 52-53, reprinted in NLRB, Legislative History at 1428-29. See also $S$ Rep 573 (74-1) at 17, reprinted in NLRB, Legislative History at 2317; remarks of Senator Wagner, NLRB Legislative History at 2338; Statement of Professor Milton Handler, Hearing of the Senate Committee on Education and Labor on S 1958 (74-1) at 233, reprinted in $N L R B$, Legislative History at 1613. 
would show that Wagner's proclamation of Adair's demise was, if not incorrect, at least exaggerated.

The Act's introductory "Findings and Policy" linked its commercial police power rationale to the rhetoric of associational liberty. ${ }^{232}$

The inequality of bargaining power between employees who do not possess full freedom of association or actual liberty of contract, and employers who are organized in the corporate or other forms of ownership association substantially burdens and affects the flow of commerce. . . . It is hereby declared to be the policy of the United States to eliminate the causes of certain substantial obstructions to the free flow of commerce and to mitigate and eliminate those obstructions when they have occurred by encouraging the practice and procedure of collective bargaining and by protecting the exercise by workers of full freedom of association. . . .

In the floor debates, moreover, proponents defended the Act in associational terms. ${ }^{233}$ But despite its evocation of associational rhetoric, the Wagner Act did not embrace the symmetrical protections for workers' associational freedom provided by earlier labor legislation. In the Senate debates on the bill, Senator Millard Tydings of Maryland sought to amend Section 7 to read: "Employees shall have the right to self-organization, to form, join, or assist labor orgamzations, to bargain collectively through representatives of their own choosing, and to engage in concerted activities, for the purpose of collective bargaining or other mutual aid or protection free from coercion or intimidation from any source." 234 The notion that workers ought to be entirely free from coercion in making associational decisions was a logical outgrowth of the associational paradigm embraced by Congress throughout the preceding decade; and the supporters of the amendment mixed associational rhetoric with citations to the Norris-LaGuardia Act in their remarks on the floor. 235 "Is this not still the kind of country," Senator Tydings asked, "where a man can select, without coercion or intimidation,

23249 Stat 449, 450 (74-1), ch 372. See Comment, 30 IIl L Rev 884, 906 (1936) ("the protection of employees in their right of freedom of association is reasonably calculated to promote the amicable settlement of disputes").

${ }^{233}$ See Irving Bernstein, Tbe Turbulent Years at 332-33 (cited in note 183).

${ }^{234}$ NLRB, Legislative History at 2357 (emphasis in original).

${ }^{235}$ See remarks of Senators Tydings, Couzens, and Hastings, NLRB, Legislative History at 2357-96. 
the kind of organization to which he shall belong?"236 "A laborer ought to be entitled without coercion from any side to say whether he wants to join this, that, or the other union, and if it is wrong for the employer, as it is wrong, to coerce labor or intimidate labor, it is equally wrong for somebody else to coerce laborers and intimidate them." 237 Opponents of the amendment were hard put to disagree with the logic of Tydings's arguments; but fearful that judges hostile to labor might interpret "coercion" to include peaceful picketing and persuasion, even Senator Norris spoke against it. ${ }^{238}$ The arguments of Waguer and Norris carried the day, and the amendment was defeated by a vote of 50-21. ${ }^{239}$

The rejection of the Tydings amendment was not the only evidence of the Senate's retreat from symmetrical associationalism. Section 9(a) of the Act provided that the representative selected by the majority of the employees in a unit would be the exclusive representative of all unit employees in negotiating the terms of employment: minority workers dissatisfied with the outcome of a certification election could not designate their own representatives to bargain on their behalf. ${ }^{240}$ President Roosevelt himself had rejected the principles of majority rule and exclusive representation on the grounds that they interfered with freedom of association when he had mediated the automobile industry settlement in 1934. ${ }^{241}$ Moreover, Section 8(3) broke with the policy of the Railway Labor Act by adopting a permissive posture toward the closed shop. The proviso to that section stipulated that "nothing in this Act . . . shall preclude an employer from making an agreement with a labor organization . . . to require as a condition of employment

${ }^{236}$ NLRB, Legislative History at 2359.

${ }^{237}$ Id at 2361.

${ }^{238}$ See remarks of Senator Norris, NLRB, Legislative History at 2380-87; see id at 2357-96 for the remarks of Senators Wagner, Barkley, and Walsh.

${ }^{239} \mathrm{NLRB}$, Legislative History at $2399-2400$. Tydings's amendment was rejected in the House without debate, id at 3216 , and was later rejected by the conference committee despite the importunings of the Secretary of Commerce. Bernstein, note 182, at 127; Cortner, Tbe Wagner Act Cases 84 (Univ Tennessee, 1964).

${ }^{240} 49$ Stat 449,453 . For Senator Hastings's unsuccessful associational objections to this provision, see $N L R B$, Legislative History at 2361, 2389-93. See Blumherg, Tbe National Labor Relations Act: A Presentation of Some Constitutional and Economic Objections, 41 Com L J 136, 138 (1936); Chandler, Tbe National Labor Relations Act, 22 ABA J 245, 250, 281-82 (1936); Comment, 30 Ill L Rev 884, 919 (1936).

${ }^{241}$ Irving Bernstein, Tbe Turbulent Years at 184-85 (cited in note 183). 
membership therein. . . ."242 In the debates over the Tydings amendment, Senator Daniel Hastings of Delaware condemned the asymmetry of the Act's protections for workers' associational liberty. The proviso, he argued, permitted "the reverse, as I understand, of the 'yellow dog' contract which has been so roundly and properly condemned in this body." 243 "Does it not say, in so many words, that if the employer so desires, and the majority of the labor union so desires, they may make an agreement whereby no one may be employed in the establishment unless he belongs to that union, and will not that provision in this bill compel a minority of employees in that particular shop or that particular unit to join that umion, whether they wish to or not, and pay all the fees which the union may desire to charge?"244 But advocates of the proviso would not engage Hastings in associational terms. Associational rhetoric had carried them as far toward their goals as it could. At this juncture, the associational rationale was abandoned; as a result, the asymmetry of the Coppage era was revived in inverted form.

The attorneys at the NLRB were aware that these provisions of the Act did not square as neatly as had the Railway Labor Act with the associational ideology expressed in the Texas \& New Orleans opinion, and they crafted their litigation strategy accordingly. ${ }^{245}$ Preparing to defend the constitutionality of the Wagner Act before the Supreme Court, the NLRB lawyers sought out test cases that would not bring before the Court these more problematic provisions of the Act. ${ }^{246}$ Each of the test cases selected therefore involved an instance in which an employer had been found guilty of an unfair labor practice under Section 8(3) because it had discharged one or more of its employees for engaging in legitimate

24249 Stat $449,452$.

${ }^{243}$ NLRB, Legislative History at 2394.

${ }^{24}$ Id at 2395. Several members of the Senate also had misgivings toward the Act's imposition of the duty to bargain. In 1934, the Senate Committee on Education and Labor had shelved Wagner's bill, S 2926, and had instead reported favorably a substitute bill introduced by Senator David I. Walsh, Democrat of Massachusetts. "Walsh believed that the government should only protect the civil right of association in a voluntary organization and that Wagner had gone too far in urging affirmative encouragement of collective bargaining." Bernstein, Tbe Turbulent Years at 195 (cited in note 183).

${ }^{245}$ James Gross, Tbe Making of tbe National Labor Relation Board 187 (State Univ of NY, 1974).

${ }^{246} \mathrm{Id}$ 
union activities. ${ }^{247}$ Such cases cleanly presented instances in which a worker's associational liberty had been compromised, and permitted the NLRB attorneys to mobilize associational rhetoric with the greatest effect.

The NLRB lawyers were also careful to select test cases in which an employer's labor relations could be said to have a direct effect on the flow of interstate commerce. Ultimately, they selected and prepared five cases (the so-called "Wagner Act cases") through which to test the constitutionality of the Act. The Washington, Virginia \& Maryland Coach Company was a small interstate transit company. The Associated Press was a national wire service utilizing interstate channels of communication. In each of these two cases, the nexus with interstate commerce was fairly clear. In addition to these cases, the NLRB also moved against three manufacturing operations: the Jones \& Laughlin Steel Corporation in Aliquippa, Pennsylvania; the Fruehauf Trailer Company in Detroit, Michigan; and the Friedman-Harry Marks Clothing Company in Richmond, Virginia. In each of these manufacturing cases, the plant in question acquired its raw and semifinished materials from points outside its home state. After transforming these materials into a finished product, each plant shipped the bulk of its products to points outside its home state. These three cases had been carefully selected because they could be argued as current of commerce cases; and, indeed, the NLRB lawyers briefed and argued the cases under that theory. ${ }^{248}$

The Wagner Act cases ${ }^{249}$ were argued at the same time as the Virginian Railway case. The Washington, Virginia \& Maryland Coach Company was admittedly a common carrier engaged in interstate commerce. Apparently recognizing that the Texas \& New Orleans case was controlling, the company offered only a token due process argument. ${ }^{250}$ None of the other businesses was so para-

\section{${ }^{247} \mathrm{Id}$}

${ }^{248}$ For a detaiIed discussion of the case selection, briefing, arguing, and resolution of the commerce clause issues in the Wagner Act cases, see Cushman, note 12, at 139-56; Irons, note 4 , at ch 11-13.

${ }^{249}$ NLRB v Jones \& Laugblin Steel Corp., 301 US 1 (1937); NLRB v Fruebauf Trailer Co., 301 US 49 (1937); NLRB v Friedman-Harry Marks Clotbing Co., 301 US 58 (1937); Associated Press Co. $v$ NLRB, 301 US 103 (1937); Wasbington, Virginia \& Maryland Coacb Co. v NLRB, 301 US 142 (1937).

${ }^{250}$ Brief for the Petitioner, at 10, 23-24, 41, Wasbington, Virginia \& Maryland Coacb Co., 301 US 142. 
digmatically public, however, and each emphasized its essentially private nature in its briefs and arguments. The Texas \& Nerw Orleans case, argued counsel for Jones \& Laughlin, was distinguishable from the instant case because the former involved "an interstate carrier, which is a public utility." 251 Congress possessed broad powers to regulate the employment practices of such enterprises. Jones \& Laughlin, however, was not a business affected with a public interest, and Congress was therefore without authority to regulate its common law prerogatives. ${ }^{252}$

The Texas \& New Orleans case, contended counsel for the Friedman-Harry Marks Clothing Company, could not "be cited in any way as authority for the proposition that the Federal Government may place any limitation upon the right of an employer conducting a private business, to hire and fire with impunity. . . ."253 The Railway Labor Act, the company argued, ${ }^{254}$

applied only to common carriers engaged in the transportation of commerce between the several states, whose businesses are affected with a great national public interest. ... (This difference is of the greatest significance and importance in a consideration of the National Labor Relations Act, which is applicable to inherently intrastate enterprises affected with no public interest, the internal regulation and continuance of which is admittedly of only private concern.)

John W. Davis, arguing on behalf of the Associated Press, contended that "regulation of the right to contract in respect of a private business, is arbitrary and therefore void unless confined to the exigencies of a real emergency." 255 The Wagner Act did "not even pretend to establish or follow a distinction between public and private business, [or] between public and private employment. . .."256 On the contrary, the Act outlawed "all private and individual bargaiming in respect of private enterprise in private industry."257 The Act as applied to the Associated Press was "an

${ }^{251}$ Brief for the Respondent at 33, Jones \& Laugblin Steel Corp., 301 US 1.

252 Id at 33, 112, 116-17.

${ }^{253}$ Brief for Respondent at 68, Friedman-Harry Marks Clotbing Co., 301 US 58 (emphasis in original).

${ }^{254}$ Id at 68-69.

${ }^{255}$ Brief for the Petitioner at 68, Associated Press Co., 301 US 103.

${ }^{256}$ Id at 70.

${ }^{257} \mathrm{Id}$. 
invasion of freedom of contract between an employer and an employee who are engaged in a wholly private occupation." 258

The Act's defenders responded, of course, by mobilizing Nebbia $v$ New York. The distinction between public and private business was no longer pertinent, and the strand of due process doctrine from which that distinction had emerged no longer constituted a restraint on the exercise of governmental regulatory power. "The Fifth Amendment," argued the attorneys for the NLRB, "serves to invalidate legislation only so far as 'the means selected' are 'unreasonable, arbitrary or capricious', and have no 'real and substantial relation to the object sought to be attained' [citing Nebbia]."259 The AFL cited Nebbia to the same effect in its amicus brief in Wasbington, Virginia \& Maryland Coach Co. ${ }^{260}$ The purpose of the Act, argued Solicitor General Stanley Reed, was to prevent interruptions to the free flow of interstate commerce caused by labor disputes, and the means selected by the Act to achieve this end were "reasonable and proper in their character."261 The due process issue was accordingly completely controlled by the Texas \& New Orleans case. ${ }^{262}$

The NLRB attorneys also mobilized associational rhetoric in defense of the Act. The Labor Board's brief in the Associated Press case contended that "the protection of employees in their freedom of association has been for a long time a recognized and fundamental part of the policy of the Federal Government in all aspects of labor relations subject to its control or legislative authority, and has been approved as just and reasonable."263 The amicus brief filed by the American Newspaper Guild in the Associated Press case crystallized the defense of the Act in a single statement: "in the public interest, it is essential to enforce freedom of association for the purpose of negotiating the terms upon which labor is willing

\footnotetext{
${ }^{258}$ Arguments, note 192, at 67.

${ }^{259}$ Brief for the Respondent at 89, Associated Press Co., 301 US 103.

${ }^{260}$ Brief of the American Federation of Labor, Amicus Curiae, at 15-16, Washington, Virginia \& Maryland Coacb Co., 301 US 142.

${ }^{261}$ Arguments, note 192, at 130-31.

262 Id at 129.

${ }^{263}$ Brief for Respondent at 96, Associated Press Co., 301 US 103; see also id at 93, 99-100; Arguments, note 192, at 86, 89.
} 
to sell its services to the end that there may be peace instead of war in matters affecting interstate commerce."264

The opinion in the Wasbington, Virginia of Maryland Coach case was, predictably, unanimous. The company was a common carrier engaged in interstate transportation, and its common law employnuent prerogatives were, like those of the Texas \& New Orleans Railroad and the Virginian Railway, subject to reasonable regulation in the public interest. In the remaiming cases, however, the Justices split $5-4$ on the due process issue. The rationales for each position were stated in the Jones \& Laugblin majority opinion and dissent. ${ }^{265}$

The principal issue before the Court was whether the labor relations of the enterprises in question were sufficiently related to the free flow of interstate commerce to warrant federal regulation under the commerce power. In the course of resolving this issue, the opinion of Chief Justice Hughes outlined the commercial police power rationale justifying the statute's intrusion upon the employer's common law prerogatives. The stoppage of Jones \& Laughlin manufacturing operations "by industrial strife," wrote Hughes, ${ }^{266}$

would have a most serious effect on interstate commerce. In view of respondent's far-flung activities, it is idle to say that the effect would be indirect or remote. It is obvious that it would be immediate and might be catastrophic. . . . When industries organize themselves on a national scale, making their relation to interstate commerce the dominant factor in their activities, how can it be maintained that their industrial labor

\footnotetext{
${ }^{264}$ Brief of the American Newspaper Guild, Amicus Curiae, at 22, Associated Press Co., 301 US 103.

${ }^{265}$ The majority opinions in the Fruebauf and Friedman-Harry Marks cases simply recited the facts and summarily sustained the application of the Act on the authority of the Jones or Laugblin decision. 301 US 49 (1937); 301 U.S. 58 (1937). The Four Horsemen offered a single consolidated dissent fron the three manufacturing cases. 301 US at 76. Justice Roberts wrote the majority opinion in the Associated Press case, in which he summarily rebuffed due process objections, citing Jones \& Laugblin and the Texas or New Orleans case. 301 US 103, 133 (1937). The Four Horsemen, having offered their liberty of contract objections to the Act in their consolidated dissent from the manufacturing cases, confined themselves to dissenting from Roberts's opinion on the ground that the application of the Act to the Associated Press violated the First Amendment. 301 US at 133.

${ }^{266}$ Jones o Laugblin, 301 US at 41 . For a detailed discussion of the commerce clause dimensions of Hughes's opinion, see Cushman, note 12, at 146-55.
} 
relations constitute a forbidden field into which Congress may not enter when it is necessary to protect interstate commerce from the paralyzing consequences of industrial war?

Revealing the extent to which the wartime experience had exposed the Adair Court's naivete, Hughes concluded: ${ }^{267}$

Experience has abundantly demonstrated that the recognition of the right of employees to self-organization and to have representatives of their own choosing for the purpose of collective bargaining is often an essential condition of industrial peace. Refusal to confer and negotiate has been one of the most prolific causes of strife. This is such an outstanding fact in the history of labor disturbances that it is a proper subject of judicial notice and requires no citation of instances.

Hughes's opinion also drew extensively on the associational rhetoric he had employed seven years earlier. Citing Texas \& New Orleans and Virginian Railway, Hughes held that the Act merely secured $^{268}$

a fundamental right. Employees have as clear a right to organize and select their representatives as the respondent has to organize its business and select its own officers and agents. Discrimination and coercion to prevent the free exercise of [those employee rights] is a proper subject for condemnation by competent legislative authority.

The Texas of New Orleans decision had clearly established that an employer's discriminatory discharge of employees constituted a coercive interference with its employees' rights of association. And with the decision in Nebbia, it was clear that the Fifth Amendment did not limit governmental power to safeguard those rights from such coercion. Deploying the post-Nebbia language of due process, the Court found that restraint of the employer's common law prerogatives "for the purpose of preventing an unjust interference with that right cannot be considered arbitrary or capricious." 269 In the conflict between liberty of contract and freedom of association, the Court had again awarded victory to the latter.

Yet as it had in Texas of New Orleans and Virginian Railway, the

${ }^{267} 301$ US at 42.

${ }^{268}$ Id at 33.

${ }^{269}$ Id at 44. 
Court minimized the Act's imposition on the employer's contractual liberty. The Act, wrote Hughes, ${ }^{270}$

imposes upon the respondent only the duty of conferring and negotiating with the authorized representatives of its employees for the purpose of settling a labor dispute. . . . The Act does not compel agreements between employers and employees. It does not compel any agreement whatever. It does not prevent the employer 'from refusing to make a collective contract and hiring individuals on whatever terms' the employer 'may by unilateral action determine.' [citing Virginian Railway].

Accordingly, Adair and Coppage were again "inapplicable." The Act did not ${ }^{271}$

interfere with the normal exercise of the right of the employer to select its employees or to discharge them. The employer may not, under cover of that right, intimidate or coerce its employees with respect to their self-organization and representation, and, on the other hand, the Board is not entitled to make its authority a pretext for interference with the right of discharge when that right is exercised for other reasons than such intimidation and coercion.

It was by now quite clear that "inapplicable" was a highly euphemistic way of describing the status of Adair. Adair and Coppage had embraced a thoroughgoing liberty of contract unchecked by a countervailing right to free association. The voluntary waiver theory of the Coppage Court had elided the conflict between these two liberal rights; and this elision was possible only against a backdrop of assumptions about the enuployment relationship that the Court no longer entertained. Changes in the structure of the labor market undoubtedly informed the Court's concept of coercion. But it is important to recognize that the distance from Adair to the Wagner Act cases was traversed within a framework of liberal rights discourse. Liberty of contract had not simply been abandoned as unworthy or anachronistic. It had instead been curtailed in order to safegnard the countervailing liberal right of free association. ${ }^{272}$

\footnotetext{
${ }^{270}$ Id at 44-45.

${ }^{271}$ Id at 45-46.

272 See Corwin, note 5, at 124-25; Corwin, Constitutional Revolution, Ltd. 66-67, 79 (Claremont, 1941); Samuel Hendel, note 165, at 260; Virginia Wood, Due Process of Law, 1932-1949 160-61 (Kennikat, 1951).
} 
The Four Horsemen were not prepared to accept this accommodation in the three manufacturing cases, and we cannot understand their reasons for doing so without attention to doctrinal detail. Like the majority, the dissenters continued to work within the analytical model fashioned in Adair. Unlike the majority, however, the dissenting Justices did not see that model as having been modified by Nebbia. Having dissented in Nebbia, the dissenters disagreed with the majority over the types of situations into which the federal government might project its authority in order to adjust the competing claims of contractual and associational freedom. The Four Horsemen thought that Congress might legitimately so project its authority in cases involving both a business affected with a public interest (as that concept had been understood before Nebbia) and a commercial police power rationale - this much the cases involving interstate common carriers made clear. ${ }^{273}$ But in the absence of these two factors, Congress was in their view powerless to intervene in the competition. Thus, despite their concurrences in the Texas \& New Orleans, Virginian Railway, and Washington, Virginia of Maryland Coacb cases, the dissenters believed that Adair and Coppage still retained some vitality.

Justice McReynolds's lengthy discussion of the commerce power issue certainly would have sufficed as a front for a dissent motivated by crude anti-labor sentiment. Yet the dissenters went on in a separate section to condemn the application of the Wagner Act to the three manufacturing establishments as a violation of the Fifth Amendment. The manner in which they did so is eloquent testimony to the continuing vitality the Adair model held for them, and to the extent to which they continued to embrace pre-Nebbian notions of public and private.

As far as the Four Horsemen were concerned, the Texas \& New Orleans case was "not controlling."274 There, Justice McReynolds wrote, the Court had been considering "an act definitely limited to common carriers engaged in interstate transportation over whose affairs Congress admittedly has wide power. . . ."275 That case had clearly dealt with a pre-Nebbia business affected with a public

${ }^{273}$ Washington, Virginia or Maryland Coach Co. $v$ NLRB, 301 US 142 (1937); Virginian Railway Co. $v$ System Federation, No. 40, 300 US 515 (1937); Texas \& New Orleans Railroad Co. $v$ Brotberbood of Railway and Steamsbip Clerks, 281 US 548 (1930).

${ }^{274}$ Friedman-Harry Marks Clotbing Co., 301 US at 101.

${ }^{275}$ Id. 
interest and an obvious commercial police power rationale. In the instant cases, however, the dissenters were not satisfied that the activities of the enterprises in question could directly affect interstate commerce. Because they viewed those enterprises as purely private businesses not affected with a public interest, the Four Horsemen could not accept the current of commerce theory urged by the government. ${ }^{276}$ Nor could they see any other theory under which the enterprises in question were anything other than simply local manufacturing operations immune from federal regulation. ${ }^{277}$ Accordingly, the impact of those employers' labor relations on interstate commerce could not provide the necessary rationale for federal police power regulation of contractual liberty.

Moreover, the businesses in which the various enterprises were engaged were not, the dissenters believed, affected with a public interest. Accordingly, the common law prerogatives of those employers to hire and fire at will were not subject to legislative abridgement. Citing Adair and Coppage, Justice McReynolds opined: ${ }^{278}$

The right to contract is fundamental and includes the privilege of selecting those with whom one is willing to assume contractual relations. This right is unduly abridged by the Act now upheld. A private owner is deprived of power to manage his own property by freely selecting those to whom his manufacturing operations are to be entrusted. We think this cannot lawfully be done in circumstances like those here disclosed.

The disagreement between the majority and the dissent over whether the Waguer Act violated the Fifth Amendment thus was a disagreement over two basic issues. First, whether the labor relations of the employers directly affected interstate commerce (the commercial police power issue); and, second, whether the businesses in which the enterprises were engaged were affected with a public interest. The disagreement over this first issue was essentially the disagreement expressed by the two sets of Justices in Nebbia $v$ New York. ${ }^{279}$ The controversy over the second issue was

\footnotetext{
${ }^{276}$ Friedman-Harry Marks Clotbing Co., 301 U.S. at 97-99, 103. See Cushman, note 12, at 154-55.

${ }^{277}$ See Cushman, note 12, at 154-55.

${ }^{278}$ Friedman-Harry Marks Clotbing Co., 301 US at 103.

${ }^{279}$ See Cushman, note 12 , at 146-56.
} 
likewise comprehended within that same Nebbian fracas. Thus, the fundamental issues that would divide the Justices in the seminal labor cases of modern American constitutional law were decided not in response to the political pressures of $1937,{ }^{280}$ but in a 1934 dispute over the price of milk in upstate New York.

\section{Conclusion}

In preparing to defend the Wagner Act, the NLRB attorneys had been forced to select their test cases and legal arguments with close attention to doctrinal detail. The Court's commerce clause jurisprudence counseled them that only businesses whose labor relations exerted a "direct" effect on interstate commerce would fall under the federal government's commercial police power. As the Four Horsemen were replaced with Roosevelt appointees, however, it appeared that the Court was taking a broader view of the federal power to regnlate commerce. The Court's 1941 decision in United States $v$ Darby ${ }^{281}$ marked a significant step in this progression; with the decision in Wickard $v$ Filburn ${ }^{282}$ the following year, the federal commerce power became virtually plenary. Taken in conjunction with the Court's decision in Nebbia, this expansion of the commercial police power made it clear that Adair's analytical model had dissolved. In 1941, Hughes's final year on the Court, Justice Frankfurter stated what must have been obvious to all. "The course of decisions in this Court since Adair v. United States and Coppage v. Kansas," he wrote, "have completely sapped those cases of their authority." 283

As the ultimate expositor of the Wagner Act, the Court would continue to define the extent of the Act's associational and contractual protections. The fundamental right of association was secure, but the legitimate concerted activities of labor associations were not without limits. ${ }^{284}$ Similarly, the abandonment of Adair and

${ }^{280}$ See Cushman, note 6.

281312 US 100 (1941).

282317 US 111 (1942).

${ }^{283}$ Pbelps-Dodge Corp. o NLRB, 313 US 177, 187 (1941) (citations omitted).

${ }^{284}$ See Karl Klare, Judicial Deradicalization of the Wagner Act and the Origins of Modern Legal Consciousness, 1937-1941, 62 Minn L Rev 265, 318-25 (1978); Nowak, Rotunda \& Young, note 8 , at $967-69$. 
Coppage did not signal a loss of all solicitude for employers' contractual prerogatives. ${ }^{285}$ The Court's constitutional accommodation between associational and contractual rights had taken place within a framework of liberal rights discourse, and the terms of that discourse would continue to inform its construction of the statute. After 1937, however, the extent of the Court's protection of those rights was no longer a matter beyond congressional control. The constitutional revolution in labor law had been consolidated.

It is a commonplace that the Hughes Court era was the period during which the Supreme Court receded from its traditional solicitude for economic liberty and began to turn its attention instead to noneconomic forms of civil liberty. Yet the story is conventionally told as if the two forms of liberty were merely ships passing in the night: one on the ascendant, the other in decline. ${ }^{286}$ In the context of the yellow-dog contract, however, the more appropriate image was the face-off. Assimilating unionism to other forms of voluntary association, labor's advocates successfully brought liberty of contract into a face-to-face conflict with freedom of association. Prefiguring and exemplifying the jurisprudential transformations for which it would become known, the Hughes Court from its inception consistently resolved this conflict in favor of associational liberty. The tale of the yellow dog thus was not just a sideshow in the demise of "laissez-faire" constitutionalism. It was emblematic of the Hughes Court's pivotal role in the recasting of American liberalism.

\footnotetext{
${ }^{285}$ Klare, supra at 293-310.

${ }^{286}$ For a discussion of historians' assessment of the Hughes Court, see Parrish, The Hughes Court, tbe Great Depression, and the Historians, 40 The Historian 286 (1978).
} 


$$
\text { - }
$$

